\title{
Facilitating student engagement through educational technology in higher education: A systematic review in the field of arts and humanities
}

\author{
Svenja Bedenlier \\ FernUniversität in Hagen, Germany \\ Melissa Bond \\ University of Oldenburg, Germany \\ Katja Buntins \\ University of Duisburg-Essen, Germany \\ Olaf Zawacki-Richter \\ University of Oldenburg, Germany \\ Michael Kerres \\ University of Duisburg-Essen, Germany
}

\begin{abstract}
Understanding how educational technology can enhance student engagement is becoming increasingly necessary in higher education, and particularly so in arts and humanities, given the communicative nature of courses. This narrative systematic review synthesises 42 peerreviewed arts and humanities articles published between 2007-2016, indexed in four international databases. The results indicate that the majority of research has been undertaken in language learning, predominantly in East Asian countries, with limited grounding of research in theory. This review found that educational technology supports student engagement, with behavioural engagement by far the most prevalent dimension. Affective engagement was the lowest observed dimension, with affective disengagement the most prevalent negative dimension. Blogs, mobile learning, and assessment tools were the most effective at promoting engagement. However, caution and education in how to use technology are needed, as any use not underpinned by effective and informed pedagogy can also lead to students feeling overwhelmed and disengaging from learning. Further research is needed on online collaboration, as well as international courses that offer cross-cultural opportunities for language use, and the increased use of qualitative methods is also advised.
\end{abstract}

Implications for practice or policy:

- Empirical research on student engagement must include a definition and be aligned to theory.

- Research must include full contextual details.

- Students need to understand the reasons behind using educational technology, be taught how to use the tools involved, and be encouraged to engage with peers and teachers through blogs, ePortfolios and collaborative tools.

- Using blogs and discussion forums can help students to model language and thereby reduce anxiety.

Keywords: systematic review, educational technology, student engagement, language learning, arts and humanities

\section{Introduction}

With the documented need for higher education graduates to be proficient in using educational technology (EdTech) in their professional lives (e.g., Organization for Economic Cooperation and Development [OECD], 2015; Redecker, 2017), as well as acquiring twenty-first century skills during their studies (Claro \& Ananiadou, 2009; Oliver \& Jorre de St Jorre, 2018), the use of EdTech in higher education has attracted increased interest from researchers, for example, in the technologies that students find helpful or unhelpful in their studies (Henderson, Selwyn, \& Aston, 2017; Selwyn, 2016) and patterns of media usage of 
(non)traditional students (Dolch \& Zawacki-Richter, 2018). Furthermore, research has found that the pedagogically informed use of technology can also support student engagement (e.g., Schindler, Burkholder, Morad, \& Marsh, 2017), a concept that has been gaining importance recently, as it links the individual student's internal constitution and external environment, leading to overall improved student outcomes (see Bond \& Bedenlier, 2019).

Whilst there are ongoing conversations about the nature of student engagement, researchers agree that it is an enigmatic and complex construct (Appleton, Christenson, \& Furlong, 2008; Kahu, 2013), with three generally accepted dimensions; behavioural, affective, and cognitive (Fredricks, Blumenfeld, \& Paris, 2004). Each dimension houses facets (called indicators by some researchers) of engagement and disengagement (Appendix A), which students experience on a continuum (Coates, 2007; Payne, 2017) of high or low activation and positive or negative valence (Pekrun \& Linnenbrink-Garcia, 2012). This study is guided by the following definition:

\begin{abstract}
Student engagement is the energy and effort that students employ within their learning community, observable via any number of behavioral, cognitive or affective indicators across a continuum. It is shaped by a range of structural and internal influences, including the complex interplay of relationships, learning activities and the learning environment. The more students are engaged and empowered within their learning community, the more likely they are to channel that energy back into their learning, leading to a range of short and long term outcomes, that can likewise further fuel engagement (Bond, Buntins, Bedenlier, Zawacki-Richter, \& Kerres, 2020, p. 3).
\end{abstract}

Given that the nexus between SE and technology use in higher education has not yet been comprehensively researched, a systematic review was conducted into this topic, comprising a total of 243 empirical studies (see Bond et al., 2020). A keyword-based search focused on "systematic review" OR "meta analysis" OR "literature review" AND "educational technology", conducted in April 2019, yielded a small number of studies that addressed the specific context of English as a second language (ESL) and English as a foreign language (EFL), as a discipline within arts and humanities (A\&H) (United Nations Educational, Scientific and Cultural Organization Institute for Statistics [UNESCO] Institute for Statistics, 2015). However, the focus of three meta-analyses identified was not on the greater concept of student engagement, but rather primarily on achievement (Chang \& Lin, 2013; Chiu, Kao, \& Reynolds, 2012; Cho, Lee, Joo, \& Becker, 2018), whilst other reviews found blended learning in ESL/EFL to be one way to enhance motivation (Albiladi \& Alshareef, 2019), and another reviewed how language learning, mediated through digital games, influenced student learning outcomes on different levels (Hung, Yang, Hwang, Chu, \& Wang, 2018). Therefore, in order to gain a broader overview, and to deepen insights into technology use within the field of $\mathrm{A} \& \mathrm{H}$, the following research questions guide this analysis:

1. What are the characteristics (countries, educational settings, study population, technology tools used) of and methods used in research on SE and EdTech in higher education, within the field of A\&H, and how do they compare to the overall sample?

2. How is research within the field of $\mathrm{A} \& \mathrm{H}$ theoretically grounded?

3. Which facets of student engagement and disengagement are affected as a result of using EdTech in the field of A\&H?

\title{
Method
}

As part of a larger research project, a systematic review was conducted into the relation of EdTech and student engagement in higher education (Gough, Oliver, \& Thomas, 2012). Clear inclusion and exclusion criteria were applied (Table 1), limiting the search to publications from 2007, to ensure that technology tools were not outdated. In order to provide transparency of the review process, a review protocol was created, which can be retrieved from ResearchGate at https://www.researchgate.net/project/Facilitatingstudent-engagement-with-digital-media-in-higher-education-ActiveLeaRn, alongside the full data set.

Screening 18,068 titles and abstracts led to 4,152 remaining references for potential inclusion (Figure 1). Due to time limitations and the large number of relevant articles in the population, a sample size estimation was carried out with the R Package MBESS (Kelley, Lai, Lai, \& Suggests, 2018), to identify a sample from this reference corpus for further analysis (Kupper \& Hafner, 1989). Under acceptance of a 5\% error range, 
a percentage of $50 \%$, and an alpha of $5 \%, 349$ articles were sampled. Taking into consideration the increased diversity of EdTech over the past years and the likewise increasing prominence of the concept of student engagement (Zepke, 2018), the articles were stratified by their year of publication. The 349 articles were screened on full text and 232 were then included, some of which reported on more than one study. Subsequently, 243 individual studies were coded, applying an inclusive code scheme.

Table 1

Final inclusion and exclusion criteria

\begin{tabular}{ll}
\hline \multicolumn{1}{c}{ Inclusion Criteria } & \multicolumn{1}{c}{ Exclusion Criteria } \\
\hline Published between 2007-2016 & Published before 2007 \\
English language & Not in English \\
Higher education & Not higher education \\
Empirical, primary research & Not empirical, primary research (e.g., review) \\
Indexed in ERIC, Web of Science, Scopus or & Evaluation or a description of a tool \\
PsycINFO & No educational technology \\
Educational technology & No learning setting \\
Student engagement & No student engagement \\
\hline
\end{tabular}

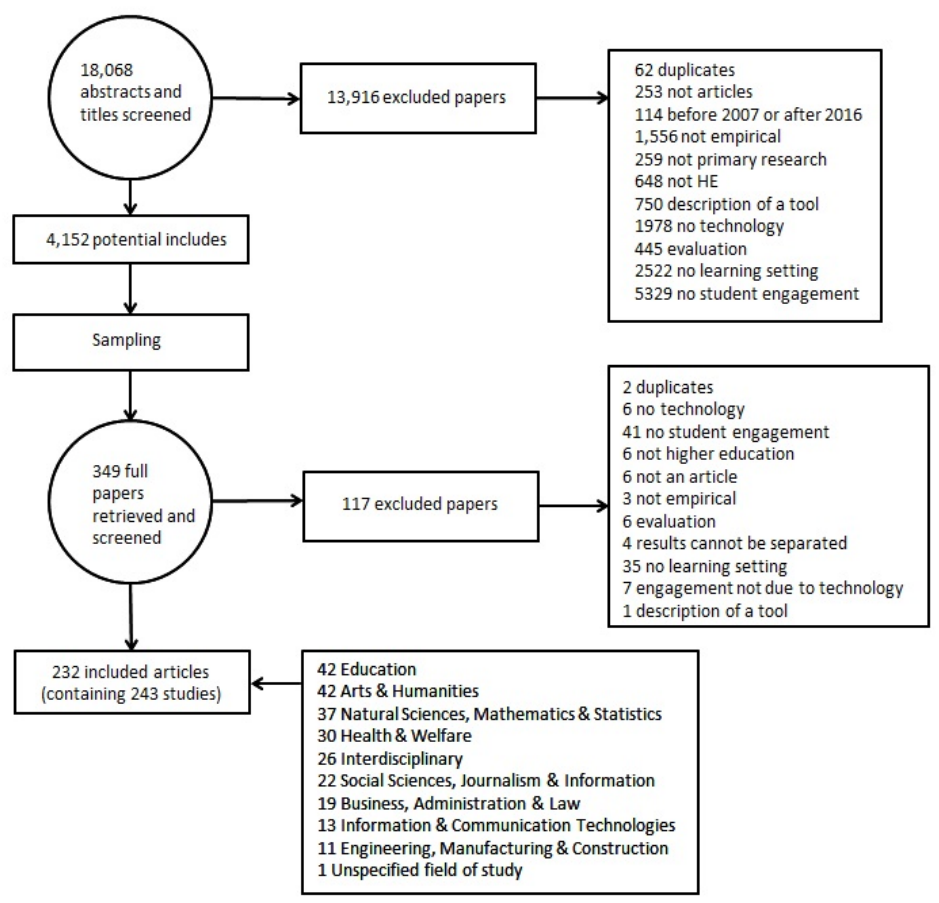

Figure 1. Systematic review PRISMA flow chart, slightly modified after Brunton and Thomas (2012, p. 86) and Moher, Liberati, Tetzlaff, \& Altman (2009, p. 8)

Due to the sheer number of educational technology tools and applications identified across the 243 studies, a problem also shared by other reviews (e.g., Lai \& Bower, 2019), the decision was made to employ Bower's (2016) typology of learning technologies (Appendix B), in order to group tools that share the same "structure of information" (Bower, 2016, p. 773). Whilst some of the tools could be classified into more than one type within the typology, for example wikis can be used for collaborative tasks, knowledge organisation and sharing, or for individual website creation, "the type of learning that results from the use of the tool is dependent on the task and the way people engage with it rather than the technology itself" therefore "the typology is presented as descriptions of what each type of tool enables and example use cases rather than prescriptions of any particular pedagogical value system" (Bower, 2016, p. 774). For a deeper explanation of each category, please see Bower (2015). 


\section{Results}

\section{Study characteristics}

Of the 42 A\&H studies, the sub-field of languages accounts for 36 studies (83.3\%) (Appendix C). English was the language most often researched $(64.8 \%, n=27)$, with six studies investigating other A\&H subjects, for example anthropology (Fukuzawa \& Boyd, 2016) or women's health and human rights (Carver, Davis, Kelley, Obar, \& Davis, 2012). The 42 studies were published in 41 articles, as Carver et al. (2012) reported on four independent studies, two of which investigated disciplines pertaining to A\&H. Studies in this sample are cited 30.95 times $(S D=44.62)$ on average.

\section{Geographical characteristics}

A total of $21.4 \%(n=9)$ were undertaken in Taiwan, followed by China $(16.7 \%, n=7)$ and the United States $(12.0 \%, n=5)$ (Figure 2). This means a clear under-representation of the United States in the field of A\&H when compared to the overall sample (-28.4\%). Less striking, but similar, this under-representation also applies to European countries such as the United Kingdom $(-10.1 \%)$, Spain $(-4.0 \%)$, and Turkey ($4.0 \%$ ). Compared to the overall sample, it is the east Asian industrialised countries of Taiwan $(17.0 \%)$, China (15.7\%), and Japan (9.5\%) that are strikingly over-represented compared to other fields, so that it can be concluded that the field of A\&H consists primarily of studies on language learning in east Asian advanced economies.

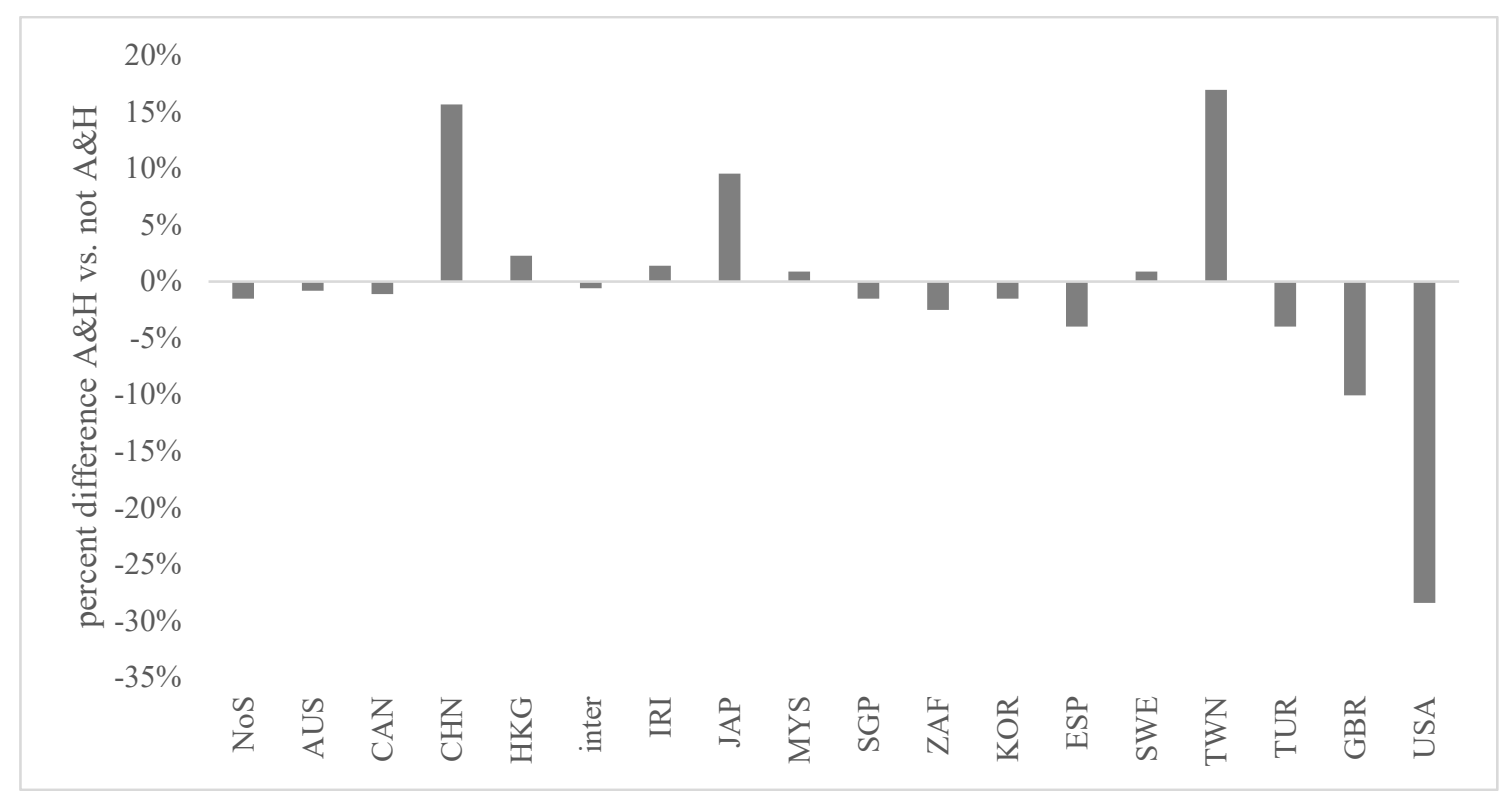

Figure 2. Percentage deviation from the average relative frequencies of articles per country ( $\geq 3$ articles in the overall sample).

Note. $\mathrm{NoS}=$ not stated; AUS = Australia; CAN = Canada; $\mathrm{CHN}=$ China; $\mathrm{HKG}=$ Hong Kong; inter $=$ international; IRI = Iran; JAP = Japan; MYS = Malaysia; SGP = Singapore; ZAF = South Africa; KOR = South Korea; ESP = Spain; SWE = Sweden; TWN = Taiwan; TUR = Turkey; GBR = United Kingdom; $\mathrm{USA}=$ United States of America

Half of the studies $(50 \%, n=21)$ took place in a blended learning format, with purely online settings used in $23.8 \%(n=10)$ and face-to-face settings used in $19.0 \%(n=8)$. However, four studies did not allow for identification of the mode of delivery used $(9.5 \%, n=4)$. Compared to the non- A\&H sample, the share of blended learning is higher in A\&H by $6.2 \%$, whilst online and face-to-face delivery occur less often (see Figure 3). The share of studies not specifying their mode of delivery is higher by $5.5 \%$ in the A\&H sample and reflects the need for further explanation of study context within future empirical research in the field.

Social collaborative learning (SCL) was employed in 76.2\% $(n=32)$, and with $38.1 \%(n=16)$, self-directed learning (SDL) was used in less than half of the studies. In another three studies $(14.3 \%)$, the learning 
scenario was not specified. Game-based learning (GBL) was used in two studies (4.8\%) and personal learning environments (PLE) in one (2.4\%). In order to determine how often learning scenarios occurred together, the number of common occurrences $\left(p_{A B}\right)$ were calculated relative to the maximum possible number of common occurrences. In concrete terms, this means that in a contingency table, the cell that indicated how often two learning scenarios occurred together is used $\left(A^{+} \wedge B^{+}\right)$and the number in this cell was determined by the smaller number of respective learning scenarios $(A \wedge B)$. Expressed as a formula:

\section{Equation 1.}

$$
p_{A B}=\frac{A^{+} \cap B^{+}}{\min \{A, B\}}
$$

In $56 \%$ of possible cases, SCL and SDL appear in combination $(n=9)$. Half of the studies using GBL were combined with SDL or SCL, with the study using PLE also having included SDL (Table 2). In the field of A\&H, SCL appears $21.1 \%$ more often than it does in the overall sample, whereas SDL occurs less often, by $6.2 \%$, than it does in the overall sample.

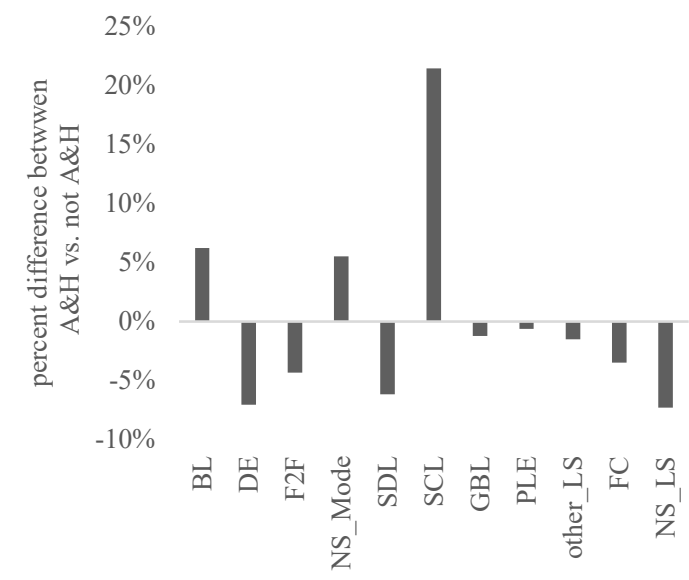

Figure 3. Percentage deviation from the average relative frequencies of mode of delivery $(n=42)$.

Note. $\mathrm{BL}=$ blended learning; $\mathrm{DE}=$ distance education; F2F = face-to-face; NS_Mode = not stated; SDL = self-directed learning; SCL = social collaborative learning; GBL = game-based learning; PLE = personal learning environments; other_LS = other learning scenario; FC = flipped classroom; NS_LS = learning scenario not stated

\section{Study population}

Interestingly, $31.0 \%$ of studies in this sample do not specify the study level of students. However, most studies $(59.5 \%, n=25)$ were conducted with undergraduate students, whilst only five studies researched graduate students $(11.9 \%)$, and one study included both undergraduate and postgraduate students (Carver et al., 2012). This distribution of study levels is significantly different from the distribution in the overall sample $\left(\chi_{(d f=3)}^{2}=9.346, \mathrm{p}<0.05\right)$. However, upon exclusion of the studies not specifying their study level, it is evident that there are fewer courses with both graduate and undergraduate students.

Controlling for the studies not specifying study level, the share of courses at postgraduate level in A\&H is at $3.4 \%$ and in the overall sample at $12.7 \%$ of studies. Controlling for this, the share of postgraduate courses in $\mathrm{A} \& \mathrm{H}$ is lower by $12.2 \%$ than in the overall sample, whereas the share of undergraduate courses is almost equal between $\mathrm{A} \& \mathrm{H}$ and the overall sample (higher by $2.9 \%$ in $\mathrm{A} \& \mathrm{H}$ ). However, these differences are not significant $\left(\chi_{(d f=2)}^{2}=2.523, \mathrm{p}>0.05\right)$ and might also have arisen due to differently structured higher education systems across countries, which is not reflected in the coding of the studies. 
Table 2

Co-occurrence of learning scenarios across the sample $(n=42)$

\begin{tabular}{|c|c|c|c|c|c|c|c|}
\hline & $\overrightarrow{\hat{n}}$ & $\vec{U}$ & $\overrightarrow{0}$ & 孚 & 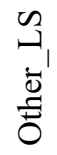 & $\bigcup_{I}$ & $\begin{array}{l}\boldsymbol{D} \\
\boldsymbol{n} \\
\boldsymbol{Z}\end{array}$ \\
\hline Sum A\&H & 16 & 32 & 2 & 1 & 0 & 0 & 3 \\
\hline SDL & & 0.56 & 0.5 & 1 & & & 0 \\
\hline $\mathrm{SCL}$ & 0.43 & & 0.5 & 0 & & & 0 \\
\hline GBL & 0.25 & 0.33 & & 0 & & & 0 \\
\hline PLE & 0.50 & 0.50 & 0 & & & & 0 \\
\hline Other_LS & 0.33 & 0.33 & 0 & 0 & & & \\
\hline $\mathrm{FC}$ & 0.57 & 0.57 & 0 & 0 & 0 & & \\
\hline NS_LS & 0 & 0 & 0 & 0 & 0 & 0 & \\
\hline Sum not A\&H & 89 & 110 & 12 & 6 & 3 & 7 & 29 \\
\hline
\end{tabular}

Note. SDL = self-directed learning; SCL = social collaborative learning; GBL = game-based learning; PLE $=$ personal learning environments; Other_LS = other learning scenario; FC = flipped classroom; NS_LS = learning scenario not stated

\section{Technology tools used}

Looking at the frequency of EdTech tools, text-based tools were used most frequently $(71.4 \%, n=30)$, followed by knowledge organisation and sharing tools $(35.7 \%, n=15)$ and multimodal production tools $(28.6 \%, n=12)$. Website creation tools and learning software were each used in $19.0 \%$ of studies $(n=8)$, assessment tools and social networking tools appeared in $14.3 \%$ of studies $(n=6)$, and mobile learning and specific hardware (e.g. iPads) were explored in $9.5 \%$ of studies $(n=4)$ across the A\&H sample.

In order to determine how often tools occurred together, the same method as that used in learning scenarios was used (Equation 1). In 93\% of cases, text-based tools were used jointly with another technology, and in $100 \%$ of cases when assessment tools were being used (Table 3). Text-based tools and learning software were used together in $88 \%$ of possible cases, and knowledge organisation and sharing tools and assessment tools in $83 \%$ of possible cases. Comparing these results with the non- A\&H studies, it is evident that textbased tools were used in A\&H 17.7\% more often, as were website creation tools (8.6\%). A striking difference between the two samples exists for learning software, which was used almost exclusively in A\&H (Figure 6). Out of the 201 studies that constitute the non-A\&H sample, only one study (Gleason, 2012) used learning software. Thus, its share in A\&H is higher by $18.6 \%$. Social networking tools were also frequently used in $\mathrm{A} \& \mathrm{H}(6.8 \%)$, whilst assessment tools (-15.1\%) and multimodal production tools ($9.7 \%$ ) were used less frequently.

\section{Methodological characteristics}

Solely quantitative methods were used in $40.5 \%$ of studies $(n=17)$, followed closely by $38.1 \%$ combining both qualitative and quantitative methods $(n=16)$, with the remaining $21.4 \%$ relying on solely qualitative methods $(n=9)$. This means that the share of mixed methods is higher by $4.3 \%$ than in the overall sample, whilst the shares of qualitative $(-2.0 \%)$ and quantitative studies $(-2.3 \%)$ are slightly smaller. The differences are, however, not significant $\left(\chi_{(d f=3)}^{2}=0.284\right)$. The most frequently used data collection method was surveys (see Table 4), followed by ability tests and observations, which included behavioural observation of student participation online, examined e.g. through the number of posts in discussion forums (e.g., Kenny, 2008).

Similar to the overall sample (see Bond et al., 2020), document analysis was only used in 10 (24\%) A\&H studies. Peterson (2012), for example, captured the chat logs of ESL students in Second Life and conducted a discourse analysis, in order to explore how students interacted and whether use of the virtual world promoted increased target language use. The majority of surveys were self-made and focused on, for 
example student satisfaction (e.g., Orawiwatnakul \& Wichadee, 2016), student perceptions of the EdTech used (e.g., Mejia, 2016) or course evaluations (e.g., Peterson, 2012), or were adapted from other studies (e.g., Lu, Hou, \& Huang, 2010).

Table 3

Co-occurrence of tools across the sample $(n=42)(\geq 3$ articles)

\begin{tabular}{|c|c|c|c|c|c|c|c|c|c|c|c|c|c|c|c|c|c|}
\hline & $\vec{n}$ & $\hat{\grave{z}}$ & $\stackrel{5}{3}$ & 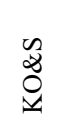 & 芯 & $\underline{n}$ & 穵 & 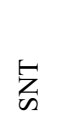 & U્山 & $\dot{\Sigma}$ & $\begin{array}{l}\bigcup_{0}^{n} \\
0 \\
\sum\end{array}$ & 3 & 约 & 0 & 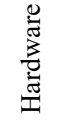 & 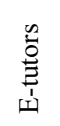 & 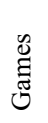 \\
\hline Sum A\&H & 30 & 12 & 8 & 15 & 0 & 0 & 6 & 6 & 5 & 4 & 0 & 2 & 8 & 0 & 4 & 2 & 0 \\
\hline TBT & & 0.75 & 0.63 & 0.93 & & & 1.00 & 0.67 & 0.80 & 0.75 & & 1.00 & 0.88 & & 0.50 & 1.00 & \\
\hline MPT & 0.57 & & 0.25 & 0.33 & & & 0.50 & 0.33 & 0.40 & 0.50 & & 0.00 & 0.25 & & 0.50 & 0.00 & \\
\hline WCT & 0.33 & 0.33 & & 0.38 & & & 0.00 & 0.50 & 0.20 & 0.00 & & 0.00 & 0.13 & & 0.00 & 0.00 & \\
\hline KO\&S & 0.69 & 0.53 & 0.52 & & & & 0.83 & 0.17 & 0.20 & 0.50 & & 0.00 & 0.25 & & 0.50 & 0.50 & \\
\hline DAT & 0.00 & 0.00 & 0.00 & 0.50 & & & & & & & & & & & & & \\
\hline DST & 1.00 & 1.00 & 1.00 & 1.00 & 0.00 & & & & & & & & & & & & \\
\hline AT & 0.51 & 0.42 & 0.10 & 0.49 & 1.00 & 1.00 & & 0.00 & 0.20 & 0.00 & & 0.00 & 0.17 & & 0.25 & 0.00 & \\
\hline SNT & 0.60 & 0.20 & 0.20 & 0.53 & 0.00 & 0.00 & 0.00 & & 0.00 & 0.00 & & 0.00 & 0.17 & & 0.00 & 0.00 & \\
\hline SCT & 0.64 & 0.64 & 0.18 & 0.45 & 0.00 & 1.00 & 0.36 & 0.18 & & 0.25 & & 0.00 & 0.00 & & 0.25 & 0.00 & \\
\hline ML & 0.17 & 0.33 & 0.17 & 0.50 & 0.00 & 0.00 & 0.17 & 0.17 & 0.00 & & & 0.00 & 0.25 & & 0.25 & 0.00 & \\
\hline MOOCs & 1.00 & 0.67 & 0.33 & 0.67 & 0.00 & 0.00 & 0.33 & 0.33 & 0.00 & 0.00 & & & & & & & \\
\hline VW & 0.38 & 0.38 & 0.06 & 0.19 & 0.00 & 0.00 & 0.31 & 0.00 & 0.18 & 0.17 & 0.00 & & 1.00 & & 0.00 & 0.00 & \\
\hline LS & 1.00 & 0.00 & 0.00 & 0.00 & 0.00 & 0.00 & 1.00 & 0.00 & 0.00 & 0.00 & 0.00 & 0.00 & & & 0.00 & 0.00 & \\
\hline $\mathrm{OL}$ & 0.50 & 0.50 & 0.10 & 0.40 & 0.00 & 0.00 & 0.50 & 0.10 & 0.00 & 0.17 & 0.00 & 0.00 & 0.00 & & & & \\
\hline Hardware & 0.36 & 0.45 & 0.18 & 0.45 & 0.00 & 1.00 & 0.18 & 0.00 & 0.36 & 0.17 & 0.00 & 0.00 & 0.00 & 0.00 & & 0.00 & \\
\hline E-tutors & 0.33 & 0.00 & 0.00 & 0.17 & 0.00 & 0.00 & 0.50 & 0.00 & 0.00 & 0.00 & 0.00 & 0.17 & 1.00 & 0.00 & 0.00 & & \\
\hline Games & 0.00 & 0.33 & 0.00 & 0.33 & 0.50 & 0.00 & 0.67 & 0.00 & 0.00 & 0.00 & 0.00 & 0.00 & 0.00 & 0.00 & 0.00 & 0.00 & \\
\hline Sum not A\&H & 108 & 77 & 21 & 89 & 2 & 1 & 59 & 15 & 11 & 6 & 3 & 16 & 1 & 10 & 11 & 6 & 3 \\
\hline
\end{tabular}

Note. $\mathrm{TBT}=$ text-based tools; $\mathrm{MPT}=$ multimodal production tools; $\mathrm{WCT}=$ website creation tools; $\mathrm{KO} \& \mathrm{~S}$ = knowledge organisation and sharing tools; DAT $=$ data analysis tools; DST $=$ digital storytelling tools; $\mathrm{AT}=$ assessment tools; $\mathrm{SNT}=$ social networking tools; $\mathrm{SCT}=$ synchronous collaboration tools; $\mathrm{ML}=$ mobile learning; $\mathrm{VW}=$ virtual worlds; $\mathrm{LS}=$ learning software; $\mathrm{OL}=$ online learning

Table 4

Data collection methods used

\begin{tabular}{lrr}
\hline Method & $n$ & Percentage \\
\hline Surveys & 23 & $54.8 \%$ \\
Ability tests & 16 & $38.0 \%$ \\
Observations & 11 & $26.2 \%$ \\
Document analysis & 10 & $23.8 \%$ \\
Interviews & 7 & $16.6 \%$ \\
Focus groups & 4 & $9.5 \%$ \\
\hline
\end{tabular}




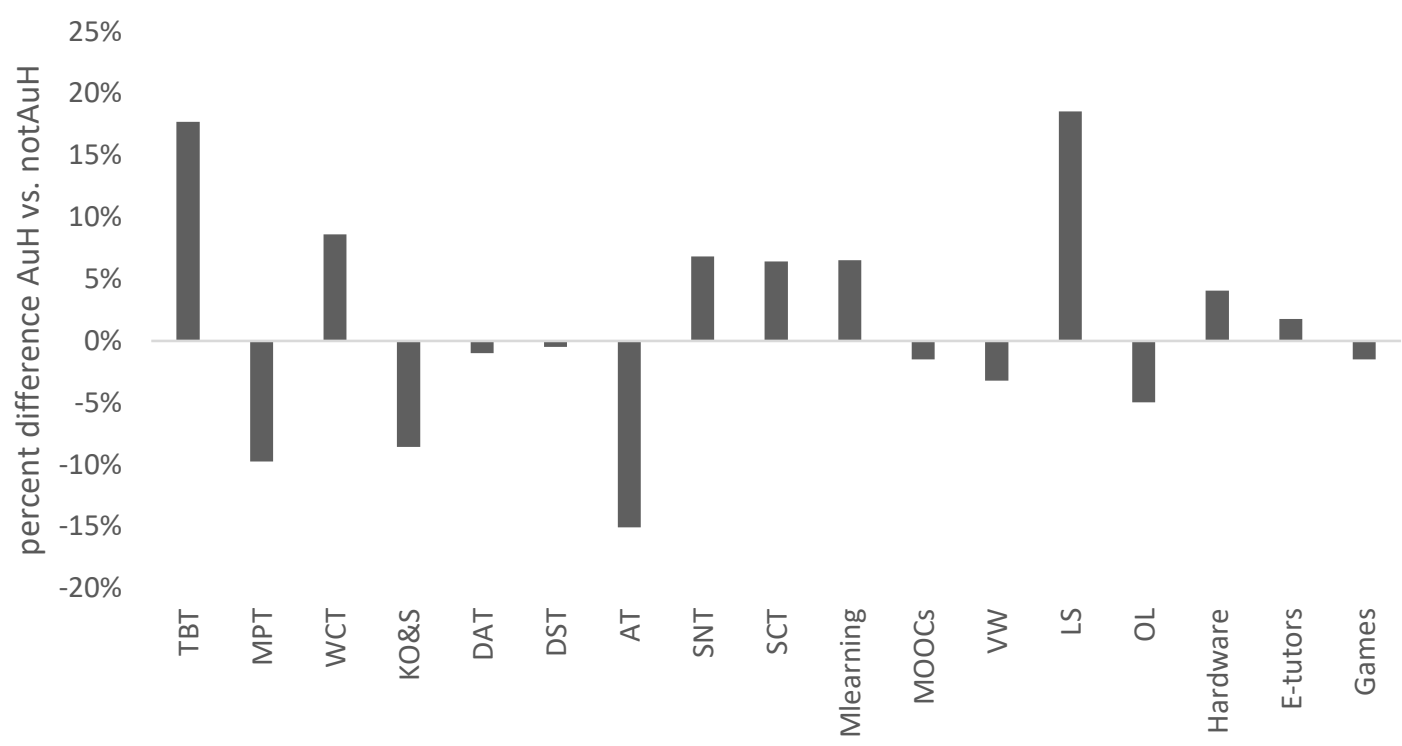

Figure 6. Percentage difference between A\&H and non- A\&H studies $(n=42)$

Note. $\mathrm{TBT}=$ text-based tools; $\mathrm{MPT}=$ multimodal production tools; $\mathrm{WCT}=$ website creation tools; KO\&S $=$ knowledge organisation and sharing tools; DAT $=$ data analysis tools; DST $=$ digital storytelling tools; AT = assessment tools; SNT = social networking tools; $\mathrm{SCT}=$ synchronous collaboration tools; MLearning = mobile learning; $\mathrm{VW}=$ virtual worlds; $\mathrm{LS}=$ learning software; $\mathrm{OL}=$ online learning.

\section{Theoretically grounding research on student engagement and educational technology}

Only two studies (4.8\%) provided a definition of student engagement (Fukuzawa \& Boyd, 2016; Lu \& Churchill, 2014). Fukuzawa and Boyd (2016, p. 1) cited a definition by Smith, Sheppard, Johnson, and Johnson (2005, p. 87), that student engagement means "the frequency with which students participate in activities that represent effective educational practice". Lu and Churchill (2014) drew on a definition by Chapman (2003), and then focused on social and cognitive engagement. A theoretical framework was applied in 20 studies (47.6\%), with constructivism referred to in four studies (Garcia-Sanchez \& RojasLizana, 2012; Lu \& Churchill, 2014; Lu et al., 2010; Shi \& Luo, 2016), social constructivism in two (Yang, Gamble, \& Tang, 2012; Zhang, Song, Shen, \& Huang, 2014) and socio-cultural theory in two studies (Lin \& Yang, 2013; Peterson, 2009). Other studies drew on Bandura's theory of social learning (Carver et al., 2012), social presence theory (Yildiz, 2009) and technological pedagogical content knowledge (TPCK) (Asoodar, Marandi, Atai, \& Vaezi, 2014). Specific to language learning in particular, Smith and Craig (2013) drew on the "theoretical framework of learner autonomy (LA) [which] is informed by principles underpinning CALL" (p. 2) and Grgurovic and Hegelheimer (2007) used interactionist second language acquisition theory.

\section{Student engagement and EdTech in the field of arts and humanities}

Behavioural engagement was by far the most prevalent dimension (Table 5), followed by cognitive and affective engagement, and in $50 \%(n=21)$ of studies, all three dimensions of student engagement were identified. Another 19\% $(n=8)$ found two dimensions, and the remaining $31 \%(n=13)$ indicated one dimension of engagement. The six most frequently cited facets of student engagement were participation/involvement/interaction, achievement, positive interactions with peers \& teachers, enjoyment and motivation, exactly replicating the top four student engagement indicators from the overall sample.

Two studies (4.8\%) found that using EdTech enhanced engagement overall, without specifying which dimensions and/or facets it referred to, which were then coded separately to the other facets. For example, in Cheung's (2015) study of mobile learning in undergraduate language study, students were asked to rate the question "I think my level of engagement using the mobile learning module for language learning was high", from strongly disagree to strongly agree. 
Table 5

Student engagement frequency descriptive statistics

\begin{tabular}{lrrcc}
\hline & Frequency & Percentage & $M$ & $S D$ \\
\hline Behavioural Engagement & 38 & $90 \%$ & 1.63 & 0.79 \\
Affective Engagement & 24 & $57 \%$ & 3.25 & 2.07 \\
Cognitive Engagement & 28 & $67 \%$ & 1.79 & 1.20 \\
\hline
\end{tabular}

\section{Behavioural engagement and educational technology}

The most frequently reported dimension of engagement was behavioural (Table 6), with participation/interaction/involvement the most cited facet $(52.4 \%, n=22)$, which was particularly present in studies using website creation tools (particularly blogs) and mobile learning (75\%), closely followed by assessment tools (Table 7). Studies often referred to the increased collaboration that online tools afforded students, as well as the ability for students to see how others constructed their questions and responses, which then enabled them to use the modelled language in their own contributions (Yang \& Hsieh, 2015). This was particularly helpful in a bilingual blog between undergraduate students at an Australian and a Spanish university, where students could read the contributions of all participating students, which "persuaded them to be more careful in their writing" (Garcia-Sanchez \& Rojas-Lizana, 2012, p. 367), and which resulted in most students interacting with each other beyond the required amount. This ability for students to interact online, without the pressure of talking face-to-face, enhanced student confidence (Yang \& Hsieh, 2015; Yildiz, 2009), as did using the target language to describe their everyday life within language courses (Mejia, 2016). Students were also more likely to interact and respond to student discussion forum posts in a Japanese ESL course, when students replied to each others' posts (Nielsen, 2013), which was found to be more important than how often the teacher contributed.

Table 6

\begin{tabular}{|c|c|c|c|c|c|c|c|c|c|}
\hline Rank & $\begin{array}{l}\text { Behavioural } \\
\text { engagement }\end{array}$ & $n$ & $\%$ & $\begin{array}{c}\text { Affective } \\
\text { engagement }\end{array}$ & $n$ & $\%$ & $\begin{array}{c}\text { Cognitive } \\
\text { engagement }\end{array}$ & $n$ & $\%$ \\
\hline 1 & $\begin{array}{l}\text { Participation/ } \\
\text { interaction/ } \\
\text { involvement }\end{array}$ & 22 & $52.4 \%$ & $\begin{array}{l}\text { Positive } \\
\text { interactions } \\
\text { with } \\
\text { peers/teachers }\end{array}$ & 14 & $33.3 \%$ & $\begin{array}{l}\text { Learning from } \\
\text { peers }\end{array}$ & 8 & $19.0 \%$ \\
\hline 2 & Achievement & 17 & $40.5 \%$ & $\begin{array}{l}\text { Enjoyment } \\
\text { Motivation }\end{array}$ & 10 & $23.8 \%$ & $\begin{array}{l}\text { Self- } \\
\text { regulation }\end{array}$ & 7 & $16.7 \%$ \\
\hline 3 & Confidence & 6 & $14.3 \%$ & Interest & 7 & $16.7 \%$ & Deep learning & 6 & $14.3 \%$ \\
\hline 4 & $\begin{array}{l}\text { Assume } \\
\text { responsibility }\end{array}$ & 5 & $11.9 \%$ & Enthusiasm & 6 & $14.3 \%$ & $\begin{array}{l}\text { Critical } \\
\text { thinking } \\
\text { Understanding }\end{array}$ & 5 & $11.9 \%$ \\
\hline 5 & Study habits & 3 & $7.1 \%$ & $\begin{array}{l}\text { Sense of } \\
\text { connectedness } \\
\text { Satisfaction } \\
\text { Excitement }\end{array}$ & 5 & $11.9 \%$ & $\begin{array}{l}\text { Staying on } \\
\text { task/focus }\end{array}$ & 4 & $9.5 \%$ \\
\hline
\end{tabular}

Three of the four studies that focused on mobile learning indicated that participation/interaction/involvement was positively affected as a result (Cheung, 2015; Ramamuruthy \& Rao, 2015; Shi \& Luo, 2016), with 45\% of students in Cheung's (2015) study agreeing or strongly agreeing that mobile learning can enhance their overall academic performance, and foreign language students who used WeChat in Shi \& Luo's (2016) study scored significantly higher $(t=2.05, P=0.039<0.05)$ than those who did not. Achievement, however, was especially found when synchronous collaborative tools, multimodal production tools (MPT) and assessment tools are used, with knowledge organisation and sharing tools and MPT having relatively high values as well. In a study examining the use and effect of voice over instant messaging on English speaking proficiency in Taiwan using Skype (Yang et al., 2012), the use of structured discussions facilitated by English teaching assistants was particularly effective, as they further scaffolded learning for students. 
Table 7

Relative frequency (percentages) of behavioural engagement facets by technology type (in 3 or more articles)

\begin{tabular}{|c|c|c|c|c|c|c|c|c|c|c|c|c|}
\hline & $\bar{Z}$ & $\stackrel{\mathscr{\vartheta}}{\vec{F}}$ & 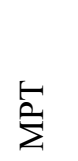 & 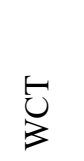 & 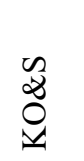 & 导 & 乬 & 㶽 & $\stackrel{\xi}{\Sigma}$ & $\tilde{U}$ & 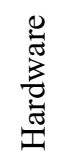 & 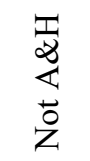 \\
\hline $\begin{array}{l}\text { Participation/ } \\
\text { interaction/ } \\
\text { involvement }\end{array}$ & $52 \%$ & $53 \%$ & $50 \%$ & $75 \%$ & $60 \%$ & $67 \%$ & $50 \%$ & $60 \%$ & $75 \%$ & $50 \%$ & $50 \%$ & $48 \%$ \\
\hline Study habits & $7 \%$ & $10 \%$ & $8 \%$ & $13 \%$ & $7 \%$ & $0 \%$ & $17 \%$ & $0 \%$ & $0 \%$ & $38 \%$ & $0 \%$ & $8 \%$ \\
\hline Confidence & $14 \%$ & $17 \%$ & $8 \%$ & $25 \%$ & $13 \%$ & $0 \%$ & $17 \%$ & $0 \%$ & $25 \%$ & $0 \%$ & $25 \%$ & $15 \%$ \\
\hline $\begin{array}{l}\text { Assume } \\
\text { responsibility }\end{array}$ & $12 \%$ & $10 \%$ & $0 \%$ & $25 \%$ & $7 \%$ & $0 \%$ & $17 \%$ & $0 \%$ & $0 \%$ & $13 \%$ & $25 \%$ & $6 \%$ \\
\hline Achievement & $40 \%$ & $40 \%$ & $50 \%$ & $25 \%$ & $47 \%$ & $50 \%$ & $17 \%$ & $60 \%$ & $25 \%$ & $38 \%$ & $25 \%$ & $44 \%$ \\
\hline
\end{tabular}

Note. TBT = text-based tools; MPT = multimodal production tools; WCT = website creation tools; KO\&S $=$ knowledge organisation and sharing tools; AT = assessment tools; SNT $=$ social networking tools; SCT $=$ synchronous collaboration tools; $\mathrm{ML}=$ mobile learning; $\mathrm{LS}=$ learning software; not $\mathrm{A} \& \mathrm{H}=$ the rest of the sample without arts and humanities

\section{Affective engagement and educational technology}

Affective engagement was noted through 10 different facets in relation to using EdTech (see Table 8), with positive interactions with peers/teachers the most cited $(33.3 \%, n=14)$, and particularly prevalent when using website creation tools and synchronous collaboration tools. Interestingly, affective engagement was seldom reported when studies used assessment tools or $\mathrm{m}$-Learning, although $\mathrm{m}$-Learning did promote enjoyment and motivation in half of the studies using it. In contrast, when using website creation tools, affective engagement was reported relatively often, especially touching upon the facets of positive interactions with peers/teachers, enjoyment and motivation. In comparison to the overall sample, motivation was found more frequently in $\mathrm{A} \& \mathrm{H}$, whilst no other striking differences exist between the two samples.

Positive interactions with peers/teachers were identified in the studies by Garcia-Sanchez \& Rojas-Lizana (2012) and Peck (2012), based on how students addressed one another in a friendly manner in an international, blog-supported language exchange course (Garcia-Sanchez \& Rojas-Lizana, 2012) or greeting their instructor more informally than would generally happen in a university course (Peck, 2012). Using blogs to provide out of class peer feedback on each other's EFL writing was very conducive to fostering increased collaboration for in-class activities of Chinese undergraduates (Zhang et al., 2014).

Students from the Open University of Hong Kong evaluated mobile learning to be both motivating for selfstudy and interesting, with $66 \%(n=40)$ stating that they (strongly) agreed with this statement, and 86 out of 87 students in the study by Garcia-Sanchez and Rojas-Lizana (2012) confirmed that the use of blogs motivated them. Motivation, however, was also fostered through a continuously present teacher in the webbased classroom (Lopera Medina, 2014), peer comments that refocused students on their written reflections, and artifacts made available to the class online (Lu \& Churchill, 2014), as well as students producing their own videos in EFL learning, to show both their creativity as well as language skills (Mejia, 2016). One student in the third study by Carver et al. (2012) commented that her level of enjoyment increased during and due to contributing to a joint Wikipedia entry "because of working on something that was not limited to our class" (p. 278) and also making it available to a larger audience. Tschirhart and Rigler (2009) found that interactive language learning materials were enjoyed by most students in two different cohorts and were perceived helpful for their learning. 
Table 8

Relative frequency (percentages) of affective engagement facets by technology type (in 3 or more articles)

\begin{tabular}{|c|c|c|c|c|c|c|c|c|c|c|c|c|}
\hline & $\bar{Z}$ & 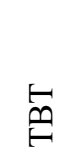 & 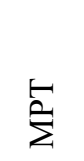 & $\stackrel{\oplus}{3}$ & $\begin{array}{l}\approx 2 \\
\ddot{\Delta} \\
0 \\
\forall\end{array}$ & 导 & 占 & 它 & $\dot{\Sigma}$ & $\stackrel{\sim}{\omega}$ & 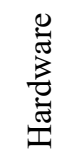 & $\begin{array}{l}\frac{\pi}{2} \\
\stackrel{2}{⿺} \\
\stackrel{0}{0}\end{array}$ \\
\hline Enthusiasm & $14 \%$ & $17 \%$ & $17 \%$ & $38 \%$ & $20 \%$ & $0 \%$ & $0 \%$ & $20 \%$ & $0 \%$ & $25 \%$ & $0 \%$ & $10 \%$ \\
\hline Interest & $17 \%$ & $20 \%$ & $25 \%$ & $25 \%$ & $20 \%$ & $17 \%$ & $0 \%$ & $20 \%$ & $25 \%$ & $25 \%$ & $25 \%$ & $15 \%$ \\
\hline Sense of belonging & $10 \%$ & $10 \%$ & $0 \%$ & $38 \%$ & $13 \%$ & $0 \%$ & $33 \%$ & $0 \%$ & $0 \%$ & $0 \%$ & $0 \%$ & $3 \%$ \\
\hline $\begin{array}{l}\text { Positive interactions with } \\
\text { peers \& teachers }\end{array}$ & $33 \%$ & $37 \%$ & $33 \%$ & $75 \%$ & $33 \%$ & $33 \%$ & $50 \%$ & $60 \%$ & $0 \%$ & $38 \%$ & $25 \%$ & $43 \%$ \\
\hline $\begin{array}{l}\text { Positive attitude about } \\
\text { learning }\end{array}$ & $10 \%$ & $10 \%$ & $0 \%$ & $25 \%$ & $13 \%$ & $0 \%$ & $17 \%$ & $0 \%$ & $0 \%$ & $13 \%$ & $25 \%$ & $16 \%$ \\
\hline Sense of connectedness & $12 \%$ & $13 \%$ & $8 \%$ & $50 \%$ & $13 \%$ & $0 \%$ & $33 \%$ & $20 \%$ & $0 \%$ & $13 \%$ & $0 \%$ & $10 \%$ \\
\hline Satisfaction & $12 \%$ & $10 \%$ & $8 \%$ & $38 \%$ & $7 \%$ & $0 \%$ & $0 \%$ & $20 \%$ & $0 \%$ & $13 \%$ & $0 \%$ & $8 \%$ \\
\hline Excitement & $12 \%$ & $17 \%$ & $17 \%$ & $38 \%$ & $0 \%$ & $0 \%$ & $33 \%$ & $20 \%$ & $0 \%$ & $13 \%$ & $0 \%$ & $7 \%$ \\
\hline Enjoyment & $24 \%$ & $27 \%$ & $33 \%$ & $50 \%$ & $20 \%$ & $0 \%$ & $17 \%$ & $20 \%$ & $50 \%$ & $50 \%$ & $25 \%$ & $22 \%$ \\
\hline Motivation & $24 \%$ & $27 \%$ & $25 \%$ & $50 \%$ & $33 \%$ & $17 \%$ & $17 \%$ & $20 \%$ & $50 \%$ & $38 \%$ & $25 \%$ & $11 \%$ \\
\hline
\end{tabular}

Note. TBT = text-based tools; MPT = multimodal production tools; WCT = website creation tools; KO\&S

= knowledge organisation and sharing tools; $\mathrm{AT}=$ assessment tools; $\mathrm{SNT}=$ social networking tools; $\mathrm{SCT}$ $=$ synchronous collaboration tools; $\mathrm{ML}=$ mobile learning; $\mathrm{LS}=$ learning software; not $\mathrm{A} \& \mathrm{H}=$ the rest of the sample without Arts \& Humanities

\section{Cognitive engagement and educational technology}

Whilst cognitive engagement was found slightly more frequently than affective engagement (Table 5), the frequency was more dispersed across the eight facets and technology tool types (Table 9). The most often identified facet was learning with peers, which occurred especially when studies used website creation tools and learning software, although the study by Lu and Churchill (2012) found that social interactions in the course did not ultimately lead to higher cognitive engagement per se. Weaker students were able to benefit from stronger ones when applying peer questioning in online discussion boards (Yang \& Hsieh, 2015), and learning from peers also happened the other way around, with tutors in EFL classes learning from their online tutees (Lin \& Yang, 2013) in the sense of feeling more prepared to be a teacher and even expanding their English vocabulary.

Self-regulation was found in studies, for example, where students' positive attitude towards technology, stemmed from the appreciation of learning by doing it on their own (Alshaikhi \& Madini, 2016). The integration of a self-study centre, as well as a reflective diary and mechanisms to track one's individual learning, led students to realise that "to find one's own way to study" (Smith \& Craig, 2013, p. 9) is a central feature of CALL. Deep learning was detected through the content analysis of student group discussions (Kenny, 2008), with findings from an investigation into the knowledge construction patterns of Taiwanese EFL students revealing that knowledge construction in online discussion occurs in relation to students' learning styles; with learners that show Serial style, rather than Holist style, showing more variation in their collaborative construction of knowledge and negotiation of meaning and disagreement $(\mathrm{Wu}, 2016)$.

Critical thinking was found to increase both in an EFL class offered in a traditional setting, but much more so in a Facebook-enhanced one $\left(d_{\mathrm{ppc} 2}=0.545\right)$ (Morris, 2008), after students were trained to answer questions developed on a revised Bloom's Taxonomy scale (Pattanapichet \& Wichadee, 2015). Installing courseware in the laboratory to enhance teacher-centered instruction, led students in the study by Tsai (2012) to develop more critical thinking skills in the sense that they reported to have improved "abilities of thinking, analysis and problem-solving" (p. 56). However, Cohen's $d=.085$ revealed no differences between the traditional and the enhanced settings. 
Table 9

Relative frequency (percentages) of cognitive engagement facets by technology type (in 3 or more articles)

\begin{tabular}{|c|c|c|c|c|c|c|c|c|c|c|c|c|}
\hline & $\bar{Z}$ & $\stackrel{\oplus}{\oplus}$ & $\stackrel{\mathfrak{E}}{\Sigma}$ & 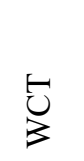 & $\begin{array}{l}\mathscr{2} \\
0 \\
1\end{array}$ & 乒 & 乬 & 记 & $\xi$ & $\tilde{\omega}$ & 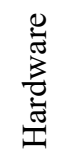 & \begin{tabular}{l}
$\frac{1}{2}$ \\
\multirow{2}{2}{} \\
0 \\
0
\end{tabular} \\
\hline Deep learning & $14 \%$ & $13 \%$ & $8 \%$ & $0 \%$ & $7 \%$ & $17 \%$ & $33 \%$ & $20 \%$ & $0 \%$ & $0 \%$ & $50 \%$ & $19 \%$ \\
\hline Self-regulation & $17 \%$ & $13 \%$ & $25 \%$ & $0 \%$ & $13 \%$ & $17 \%$ & $33 \%$ & $0 \%$ & $0 \%$ & $25 \%$ & $0 \%$ & $16 \%$ \\
\hline $\begin{array}{l}\text { Staying on } \\
\text { task/focus }\end{array}$ & $10 \%$ & $13 \%$ & $8 \%$ & $25 \%$ & $7 \%$ & $0 \%$ & $17 \%$ & $20 \%$ & $25 \%$ & $25 \%$ & $0 \%$ & $9 \%$ \\
\hline $\begin{array}{l}\text { Positive perceptions } \\
\text { of teacher support }\end{array}$ & $7 \%$ & $10 \%$ & $17 \%$ & $25 \%$ & $7 \%$ & $17 \%$ & $17 \%$ & $20 \%$ & $0 \%$ & $13 \%$ & $0 \%$ & $8 \%$ \\
\hline $\begin{array}{l}\text { Follow } \\
\text { through/Care/ } \\
\text { thoroughness }\end{array}$ & $7 \%$ & $10 \%$ & $8 \%$ & $13 \%$ & $13 \%$ & $0 \%$ & $17 \%$ & $0 \%$ & $25 \%$ & $0 \%$ & $25 \%$ & $7 \%$ \\
\hline $\begin{array}{l}\text { Learning from } \\
\text { peers }\end{array}$ & $19 \%$ & $23 \%$ & $8 \%$ & $38 \%$ & $13 \%$ & $0 \%$ & $17 \%$ & $20 \%$ & $0 \%$ & $38 \%$ & $0 \%$ & $23 \%$ \\
\hline Critical Thinking & $12 \%$ & $7 \%$ & $8 \%$ & $0 \%$ & $0 \%$ & $0 \%$ & $33 \%$ & $0 \%$ & $25 \%$ & $0 \%$ & $0 \%$ & $10 \%$ \\
\hline Understanding & $12 \%$ & $13 \%$ & $8 \%$ & $0 \%$ & $13 \%$ & $17 \%$ & $17 \%$ & $20 \%$ & $25 \%$ & $13 \%$ & $0 \%$ & $4 \%$ \\
\hline
\end{tabular}

Note. $\mathrm{TBT}=$ text-based tools; MPT $=$ multimodal production tools; $\mathrm{WCT}=$ website creation tools; KOS = knowledge organisation and sharing tools; AT = assessment tools; SNT = social networking tools; SCT = synchronous collaboration tools; $\mathrm{ML}=$ mobile learning; $\mathrm{LS}=$ learning software; not $\mathrm{A} \& \mathrm{H}=$ the rest of the sample without Arts \& Humanities

\section{Student disengagement and educational technology in the field of arts and humanities}

Student disengagement (Table 10) was found considerably less often across the sample, which could be due to studies seeking to identify positive engagement, although this could also be potentially due to a form of publication or self-selection bias, due to infrequent publishing of studies with negative results. The three disengagement facets most often indicated were frustration $(n=5,11.9 \%)$, half-hearted/task incompletion $(n=3,7.1 \%)$, and pressured $(n=3,7.1 \%)$.

Table 10

Student disengagement frequency descriptive statistics

\begin{tabular}{lcccc}
\hline & Frequency & Percentage & $M$ & $S D$ \\
\hline Behavioural Disengagement & 5 & $12 \%$ & 2 & 1.41 \\
Affective Disengagement & 10 & $24 \%$ & 1.6 & 0.84 \\
Cognitive Disengagement & 6 & $14 \%$ & 1.5 & 0.84 \\
\hline
\end{tabular}

\section{Behavioural disengagement and educational technology}

Behavioural disengagement was indicated by six facets (Table 11), with the most frequent of these being half-hearted/task incompletion (Table 12), which was the only facet identified in three or more studies. This was related to students not completing their share of the group work in a blended or online class respectively (Asoodar et al., 2014), not sufficiently contributing to group discussion forums (Wang, 2010) or using the provided forum, chat or e-mail only very superficially (Lopera Medina, 2014). In the case of group work in Wang (2010), groups were comprised of students from two different colleges, with students from one college posting more or less nothing, which in turn led the students from the other college to interact among themselves - thus, half-hearted participation did not stop interaction and dialogue, but rather gave it an unintended direction. When looking at the facets of unfocused/inattentive and distracted, it is noteworthy, albeit not surprising, that the Internet is cited as a prime reason for losing focus and being distracted, as one EFL student in a blended learning course pointed out (Zhang \& Han, 2012). The authors conclude that students' ability to learn autonomously needs to be increased, as well as the provision of teacher guidance. 
Table 11

Top five disengagement facets across the three dimensions

\begin{tabular}{|c|c|c|c|c|c|c|c|c|c|}
\hline Rank & $\mathrm{BD}$ & $n$ & $\%$ & $\mathrm{AD}$ & $n$ & $\%$ & $\mathrm{CD}$ & $n$ & $\%$ \\
\hline 1 & $\begin{array}{l}\text { Half-hearted/task } \\
\text { incompletion }\end{array}$ & 3 & $7.1 \%$ & Frustration & 5 & $11.9 \%$ & Pressured & 3 & $7.1 \%$ \\
\hline 2 & $\begin{array}{l}\text { Unfocused } \\
\text { Distracted }\end{array}$ & 2 & $4.8 \%$ & $\begin{array}{l}\text { Disinterest } \\
\text { Disappointment } \\
\text { Worry/Anxiety } \\
\text { Other }\end{array}$ & 2 & $4.8 \%$ & $\begin{array}{l}\text { Opposition/ } \\
\text { Rejection } \\
\text { Other }\end{array}$ & 2 & $4.8 \%$ \\
\hline 3 & $\begin{array}{l}\text { Giving up } \\
\text { Mentally withdrawn } \\
\text { Poor conduct }\end{array}$ & 1 & $2.4 \%$ & & & & Unwilling & 1 & $2.4 \%$ \\
\hline
\end{tabular}

Note. $\mathrm{BD}=$ Behavioural disengagement; $\mathrm{AD}=$ affective disengagement; $\mathrm{CD}=$ cognitive disengagement.

Table 12

Relative frequency (percentages) of behavioural disengagement facets by technology type (in 3 or more articles)

\begin{tabular}{|c|c|c|c|c|c|c|c|c|c|c|c|c|}
\hline & 齐 & $\stackrel{\vec{\vartheta}}{\hat{F}}$ & $\hat{\sum}$ & $\begin{array}{l}\ominus \\
3\end{array}$ & $\begin{array}{l}\mathscr{y} \\
0 \\
0 \\
\forall\end{array}$ & 昏 & 㤐 & $\underset{\mathscr{U}}{\ominus}$ & 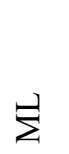 & $\tilde{\omega}$ & 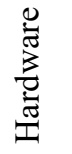 & \begin{tabular}{l}
$\frac{\pi}{1}$ \\
\multirow{2}{\alpha}{} \\
0 \\
0 \\
0
\end{tabular} \\
\hline $\begin{array}{l}\text { Half- } \\
\text { hearted/task } \\
\text { incompletion }\end{array}$ & $7 \%$ & $10 \%$ & $8 \%$ & $13 \%$ & $13 \%$ & $17 \%$ & $0 \%$ & $20 \%$ & $0 \%$ & $13 \%$ & $0 \%$ & $8 \%$ \\
\hline
\end{tabular}

Note. $\mathrm{TBT}=$ text-based tools; $\mathrm{MPT}=$ multimodal production tools; $\mathrm{WCT}=$ website creation tools; KO\&S $=$ knowledge organisation and sharing tools; $\mathrm{AT}=$ assessment tools; $\mathrm{SNT}=$ social networking tools; $\mathrm{SCT}$ = synchronous collaboration tools; $\mathrm{ML}=$ mobile learning; $\mathrm{LS}=$ learning software; not $\mathrm{A} \& \mathrm{H}=$ the rest of the sample without Arts \& Humanities

\section{Affective disengagement and educational technology}

Four affective disengagement facets were coded alongside other (Table 11), with frustration the most frequent (Table 13). Students were particularly frustrated by technical issues experienced with technology (Ducate, Anderson, \& Moreno, 2011), such as Google docs being occasionally unstable and lagging during group work (Lin \& Yang, 2013), and fellow students changing the background and font colours of online group spaces, which made writing uncomfortable for some (Asoodar et al., 2014). For one student, the lack of an option to hand in work without technology meant that "if you didn't have easy access to technology or had technological difficulties, you were disadvantaged" (Mejia, 2016, p. 90) and other students were worried that late submission as a result might mean incurring a penalty. Students using Second Life in an undergraduate ESL course found that interacting with fellow students could also be challenging, and noted the need for good typing skills, however they also felt that the setting was less stressful than a regular language class (Peterson, 2012).

Table 13

Relative frequency of affective disengagement facets by technology type (in 3 or more articles)

\begin{tabular}{|c|c|c|c|c|c|c|c|c|c|c|c|c|}
\hline & $\bar{z}$ & $\vec{\varphi}$ & $\stackrel{5}{\Sigma}$ & $\begin{array}{l}5 \\
3\end{array}$ & 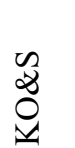 & 安 & 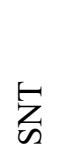 & ț & $\vec{\Sigma}$ & $\Omega$ & 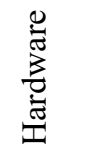 & 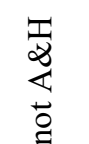 \\
\hline Fustration & $12 \%$ & $17 \%$ & $25 \%$ & $13 \%$ & $7 \%$ & $0 \%$ & $0 \%$ & $20 \%$ & $25 \%$ & $13 \%$ & $25 \%$ & $14 \%$ \\
\hline
\end{tabular}

Note. TBT = text-based tools; MPT = multimodal production tools; WCT = website creation tools; KO\&S

$=$ knowledge organisation and sharing tools; AT = assessment tools; SNT = social networking tools; SCT

= synchronous collaboration tools; $\mathrm{ML}=$ mobile learning; $\mathrm{LS}=$ learning software; not $\mathrm{A} \& \mathrm{H}=$ the rest of the sample without Arts \& Humanities 
Students who were disinterested in using EdTech included those who were negative or cynical about the tools used, such as Ning (Peck, 2012). Students also expressed disappointment when interactions with peers were made difficult through technology, due to not being able to read a person's body language and interpret their meaning in messages (Yildiz, 2009). Students in a web-based graduate ESL course "expressed a high degree of anxiety when they did not receive an automated score from the exercises they had submitted" (Lopera Medina, 2014, p. 97), as some of the tasks had to be graded manually by the instructor, which was demotivating for students. Also causing concern for one student was the use of an interactive whiteboard in a beginners' Chinese course, as they did not want to embarrass themselves in front of other students (Xu \& Moloney, 2011), and a lack of technology skills and experience with online communication within educational contexts caused difficulties for others (Lopera Medina, 2014; Wang, 2010).

\section{Cognitive disengagement and educational technology}

As with affective disengagement, there were only four facets of cognitive disengagement coded in this sample, alongside other (Table 11), with pressured the most cited (Table 14). Three studies that explored blended learning in ESL classes (Asoodar et al., 2014; Sun, 2014; Zhang \& Han, 2012) found that students felt pressured because "they had to devote themselves to both the online environment and the classroom environment and they had to spend much more time on English learning, which was stressful for them" (Zhang \& Han, 2012, p. 1967). This led one student to declare that "only in the traditional classroom, can I acquire basic English" (Sun, 2014, p. 90). Another student felt overwhelmed, as their lack of a computer at home meant they often had to go to the university campus, which "took a lot of [their] time" (Asoodar et al., 2014, p. 540), and the use of M-Learning in a face-to-face beginners' Spanish course was stressful for some students, as technical problems caused difficulties in handing up assignments (Mejia, 2016). Students were opposed to online group work in blended classes in two studies, as they preferred to "meet face-toface" (Asoodar et al., 2014, p. 538), with students in a blended undergraduate Linguistics course "openly ridicul[ing]" (Peck, 2012, p. 83) the idea that they might develop offline friendships with fellow students, and unwilling to engage in online discussions with the lecturer.

Table 14

Relative frequency (percentages) of cognitive disengagement facets by technology type (in 3 or more articles)

\begin{tabular}{|c|c|c|c|c|c|c|c|c|c|c|c|c|}
\hline & $\bar{Z}$ & $\stackrel{\vec{n}}{\vec{F}}$ & 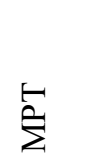 & $\begin{array}{l}\ominus \\
3\end{array}$ & $\begin{array}{l}\mathscr{Z} \\
\ddot{z} \\
0 \\
\forall\end{array}$ & 艺 & 占 & 记 & $\exists$ & 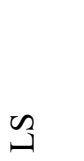 & 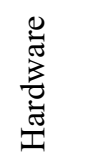 & 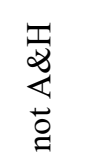 \\
\hline Pressured & $7 \%$ & $10 \%$ & $25 \%$ & $13 \%$ & $13 \%$ & $17 \%$ & $0 \%$ & $20 \%$ & $25 \%$ & $0 \%$ & $25 \%$ & $6 \%$ \\
\hline
\end{tabular}

Note. TBT = text-based tools; MPT = multimodal production tools; WCT = website creation tools; KO\&S $=$ knowledge organisation and sharing tools; $\mathrm{AT}=$ assessment tools; $\mathrm{SNT}=$ social networking tools; $\mathrm{SCT}$ = synchronous collaboration tools; $\mathrm{ML}=$ mobile learning; $\mathrm{LS}=$ learning software; not $\mathrm{A} \& \mathrm{H}=$ the rest of the sample without Arts \& Humanities

\section{Discussion}

\section{Grounding arts and humanities research in theory and methodologies used}

A common theme within research on student engagement has been the complexity of the construct, and in particular, its definition and measurement. This was particularly evident within the overall sample, but more so within this subset, as only two studies (5\%) included a definition. Whilst arguments will most likely continue over the exact nature of student engagement, it is vital that each study investigating engagement includes a definition of their own understanding, in order to locate and frame their findings, and to ensure easier interpretation of results (Appleton et al., 2008; Christenson, Reschly, \& Wylie, 2012). It is also advised that studies relate the aspects of engagement under investigation to the wider framework of student engagement (see e.g., Bond \& Bedenlier, 2019), and to further consider the issue of disengagement when using EdTech, given that engagement and disengagement exist on a continuum (Pekrun \& Linnenbrink- 
Garcia, 2012), and few studies within this sample explored the negative effects of EdTech, despite the valuable insight for educators that such investigations could provide.

More than half of the studies in this sample did not use a theoretical framework, which mirrors current conversations and concerns within the wider field of EdTech (e.g., Crook, 2019; Hew, Lan, Tang, Jia, \& Lo, 2019). Studies that did, drew heavily on constructivism and socio-cultural theories of learning and practice, with three quarters using social collaborative approaches, also reflective of the trend in EdTech research (Bond, Zawacki-Richter, \& Nichols, 2019). Interestingly, given the high number of studies relating to language learning in the sample, only two studies drew on language specific theories. This perhaps emphasises the importance now placed within research on language within social contexts and language learning as a social endeavour (Chapelle, 2009; Thorne, Black, \& Sykes, 2009), or, as Garrett (2009) suggests, perhaps this is due to the normalisation of technology use within higher education.

Whilst the number of studies that used qualitative methods was not greatly different to the overall sample, there were nevertheless a smaller amount of studies that used, for example, interviews and focus groups. Given the large number of studies that used text-based tools $(71.4 \%)$, and the focus of this sample on language learning and use, it was also surprising that fewer studies used document analysis. As student engagement is complex, it is important to also use data collection methods that provide thick descriptions of student and teacher perceptions of using EdTech, rather than solely relying on quantitative data, which often focuses more on behavioural engagement (Fredricks et al., 2004; Henrie, Halverson, \& Graham, 2015). This more quantitative approach towards EdTech in A\&H could perhaps be partially explained in this sample, given the large amount of Asian studies present, and the fact that quantitative methods were heavily used in Asian countries in the overall sample. Caution is advised, however, with using selfdeveloped surveys over previously validated instruments, as this can pose questions of validity and reproducibility (Döring \& Bortz, 2016).

There were also issues of missing contextual data within the studies in this sample. Without full contextual information in empirical research, readers are unable to fully gauge whether studies could be applied to their own context (Bond, Zawacki-Richter, \& Nichols, 2019; Pérez-Sanagustín et al., 2017), and more explicit study details should be included in future research.

\section{Educational technology and student engagement}

The synthesised findings from the studies in this sample can be broadly read as an affirmation of the argument that the mere use of technology as such does not make learning better, but is rather only one factor in the design of a course or module (Tamim, Bernard, Borokhovski, Abrami, \& Schmid, 2011). This can be gathered from the fact that authentic and meaningful tasks, such as using Wikipedia to create a contribution extending the classroom (e.g., Carver et al., 2012) were perceived by students to be more enjoyable or that collaborative activities were found to be effective when using e.g. digital flashcards in language learning (Hung, 2015).

Whilst blended learning was used in half of the studies, students in language learning courses (e.g., Zhang $\&$ Han, 2012) reported being somewhat opposed to the online parts of the course, feeling pressured or overwhelmed, and preferring the face-to-face environment for learning. However, studies also found that using blogs and discussion forums allowed students to see examples of other students' work and therefore model language in their own responses, which reduced anxiety. They were also more likely to contribute more if other students responded to their posts. Interestingly, whilst affective engagement appeared less often in this A\&H sample, affective disengagement occurred more frequently than behavioural and cognitive disengagement (see Table 10). Practitioners, therefore, need to be particularly mindful of the potential for students to become disengaged, and to be proactive in taking preventative measures. Frustration was primarily related to technical problems and failures (e.g., Ducate et al., 2011), such as unstable connections or programs not functioning as expected (e.g., Lin \& Yang, 2013), and disengagement also particularly manifested in students not completing group work or contributing to discussion forums (e.g., Wang, 2010). If technology and online learning are to be used in a course, it is therefore important to make both tasks and the use of technology valuable to students and conducive to learning goals. It is also important to then ensure that students understand the reasons behind utilising EdTech, are taught how to use the tools involved, and are encouraged to engage with their peers as much as possible. 


\section{Conclusion}

This study synthesised 42 studies in the field of $\mathrm{A} \& \mathrm{H}$, the majority of which addressed language learning, and ESL/EFL in particular. A considerable number of studies were undertaken in East Asian countries, with Taiwan contributing seven studies alone. This raises questions as to how this heavy regional and disciplinary focus can be explained, as well as how EdTech is employed in other disciplines within A\&H, such as history, performing arts or religious studies (UNESCO, 2015). Also, given that regions such as continental Europe, Africa and Oceania were only minimally present in this sample, further investigation is encouraged within those regions, as learning is rooted in cultural contexts and occurs against specific institutional background and learner characteristics. With more countries, and a broader range of institutional settings and disciplines explored, a more holistic picture can potentially be gained of how EdTech can be effectively used to enhance student engagement.

The authors sought to adhere to the principles of conducting a systematic review as closely as possible. However, the implicit bias of having searched only English language databases and the explicit restriction to journal articles from the years 2007 to 2016 , constitute a limitation to the results of this study. In order to capture more recent and emerging technologies, including artificial intelligence, it is suggested that this review be updated accordingly in the future.

\section{Funding}

This work was supported by the Bundesministerium für Bildung und Forschung (German Federal Ministry of Education and Research - BMBF) [grant number 16DHL1007].

\section{References}

Albiladi, W. S., \& Alshareef, K. K. (2019). Blended learning in English teaching and learning: A review of the current literature. Journal of Language Teaching and Research, 10(2), 232-238. https://doi.org/10.17507/jltr.1002.03

Alshaikhi, D., \& Madini, A. A. (2016). Attitude toward enhancing extensive listening through podcasts supplementary pack. English Language Teaching, 9(7), 32. https://doi.org/10.5539/elt.v9n7p32

Appleton, J., Christenson, S. L., \& Furlong, M. (2008). Student engagement with school: Critical conceptual and methodological issues of the construct. Psychology in the Schools, 45(5), 369-386. https://doi.org/10.1002/pits.20303

Asoodar, M., Marandi, S. S., Atai, M. R., \& Vaezi, S. (2014). Learner reflections in virtual vs. blended EAP classes. Computers in Human Behavior, 41, 533-543. https://doi.org/10.1016/j.chb.2014.09.050

Bond, M. (2019). Flipped learning and parent engagement in secondary schools: A South Australian case study. British Journal of Educational Technology, 50(3), 1294-1319. https://doi.org/10.1111/bjet.12765

Bond, M., \& Bedenlier, S. (2019). Facilitating student engagement through educational technology: Towards a conceptual framework. Journal of Interactive Media in Education, 2019(1): 11, 1-14. https://doi.org/10.5334/jime.528

Bond, M., Buntins, K., Bedenlier, S., Zawacki-Richter, O., \& Kerres, M. (2020). Mapping research in student engagement and educational technology in higher education: A systematic evidence map. International Journal of Educational Technology in Higher Education, 17(1), 1-30. https://doi.org/10.1186/s41239-019-0176-8

Bond, M., Zawacki-Richter, O., \& Nichols, M. (2019). Revisiting five decades of educational technology research: A content and authorship analysis of the British Journal of Educational Technology. British Journal of Educational Technology, 50(1), 12-63. https://doi.org/10.1111/bjet.12730

Bower, M. (2015). A typology of Web 2.0 learning technologies. EDUCAUSE Digital Library. Retrieved from http://www.educause.edu/library/resources/typology-web-20-learning-technologies

Bower, M. (2016). Deriving a typology of Web 2.0 learning technologies. British Journal of Educational Technology, 47(4), 763-777. https://doi.org/10.1111/bjet.12344

Brunton, J., \& Thomas, J. (2012). Information management in systematic reviews. In D. Gough, S. Oliver, \& J. Thomas (Eds.), An introduction to systematic reviews (pp. 83-106). London: SAGE. 
Carver, B. W., Davis, R., Kelley, R. T., Obar, J. A., \& Davis, L. L. (2012). Assigning students to edit Wikipedia: Four case studies. E-Learning and Digital Media, 9(3), 273-283. https://doi.org/10.2304/elea.2012.9.3.273

Chang, M. M., \& Lin, M.-C. (2013). Strategy-oriented web-based English instruction - A meta-analysis. Australasian Journal of Educational Technology, 29(2), 203-216. https://doi.org/10.14742/ajet.67

Chapelle, C. A. (2009). The relationship between second language acquisition theory and computerassisted language learning. The Modern Language Journal, 93(s1), 741-753. https://doi.org/10.1111/j.1540-4781.2009.00970.x

Chapman, E. (2003). Assessing student engagement rates. Retrieved from http://www.ericdigests.org/2005-2/engagement.html

Chen, C.-M., \& Chang, C.-C. (2014). Mining learning social networks for cooperative learning with appropriate learning partners in a problem-based learning environment. Interactive Learning Environments, 22(1), 97-124. https://doi.org/10.1080/10494820.2011.641677

Cheung, S. K. S. (2015). A case study on the students' attitude and acceptance of mobile learning. In: Li, K.C., Wong, T.L., Cheung, S. K. S., Lam, J., Ng, K. K. (Eds.). Technology in Education. Transforming Educational Practices with Technology. Communications in Computer and Information Science (pp. 45-54), vol. 494. Berlin: Springer. https://doi.org/10.1007/978-3-662-46158-7 5

Chiu, Y., Kao, C., \& Reynolds, B. L. (2012). The relative effectiveness of digital game-based learning types in English as a foreign language setting: A meta-analysis. British Journal of Educational Technology, 43(4), E104-E107. https://doi.org/10.1111/j.1467-8535.2012.01295.x

Cho, K., Lee, S., Joo, M-H., \& Becker, J. B. (2018). The effects of using mobile devices on student achievement in language learning: A meta-analysis. Education Sciences, 8(3), 1-16. https://doi.org/10.3390/educsci8030105

Christenson, S. L., Reschly, A. L., \& Wylie, C. (Eds.) (2012). Handbook of research on student engagement. Boston, MA: Springer. https://doi.org/10.1007/978-1-4614-2018-7

Claro, M., \& Ananiadou, K. (2009). 21 st century skills and competences for new millennium learners in OECD countries (OECD Education Working Papers No. 41). Paris: OECD. https://doi.org/10.1787/218525261154

Coates, H. (2007). A model of online and general campus-based student engagement. Assessment \& Evaluation in Higher Education, 32(2), 121-141. https://doi.org/10.1080/02602930600801878

Crook, C. (2019). The "British" voice of educational technology research: 50th birthday reflection. British Journal of Educational Technology, 50(2), 485-489. https://doi.org/10.1111/bjet.12757

Dolch, C., \& Zawacki-Richter, O. (2018). Are students getting used to learning technology? Changing media usage patterns of traditional and non-traditional students in higher education. Research in Learning Technology, 26(0). https://doi.org/10.25304/rlt.v26.2038

Döring, N., \& Bortz, J. (2016). Forschungsmethoden und Evaluation in den Sozial- und Humanwissenschaften. Berlin: Springer. https://doi.org/10.1007/978-3-642-41089-5

Ducate, L. C., Anderson, L. L., \& Moreno, N. (2011). Wading through the world of wikis: An analysis of three wiki projects. Foreign Language Annals, 44(3), 495-524. https://doi.org/10.1111/j.19449720.2011.01144.x

Filsecker, M., \& Kerres, M. (2014). Engagement as a volitional construct. Simulation \& Gaming, 45(4-5), 450-470. https://doi.org/10.1177/1046878114553569

Fredricks, J., Blumenfeld, P. C., \& Paris, A. H. (2004). School engagement: Potential of the concept, state of the evidence. Review of Educational Research, 74(1), 59-109. https://doi.org/10.3102/00346543074001059

Fredricks, J. A., Filsecker, M., \& Lawson, M. A. (2016). Student engagement, context, and adjustment: Addressing definitional, measurement, and methodological issues. Learning and Instruction, 43, 1-4. https://doi.org/10.1016/j.learninstruc.2016.02.002

Fukuzawa, S., \& Boyd, C. (2016). Student engagement in a large classroom: Using technology to generate a hybridized problem-based learning experience in a large first year undergraduate class. Canadian Journal for the Scholarship of Teaching and Learning, 7(1), 1-14. https://doi.org/10.5206/cjsotl-rcacea.2016.1.7

Garcia-Sanchez, S., \& Rojas-Lizana, S. (2012). Bridging the language and cultural gaps: The use of blogs. Technology Pedagogy and Education, 21(3), 361-381.

https://doi.org/10.1080/1475939x.2012.719396 
Garrett, N. (2009). Computer-assisted language learning trends and issues revisited: Integrating innovation. The Modern Language Journal, 93(s1), 719-740. https://doi.org/10.1111/j.15404781.2009.00969.x

Gleason, J. (2012). Using technology-assisted instruction and assessment to reduce the effect of class size on student outcomes in undergraduate mathematics courses. College Teaching, 60(3), 87-94. https://doi.org/10.1080/87567555.2011.637249

Gough, D., Oliver, S., \& Thomas, J. (Eds.) (2012). An introduction to systematic reviews. Thousand Oaks, CA: SAGE.

Grgurović, M., \& Hegelheimer, V. (2007). Help options and multimedia listening: Students' use of subtitles and the transcript. Language Learning and Technology, 11(1), 45-66. Retrieved from https://scholarspace.manoa.hawaii.edu/bitstream/10125/44088/1/11 01 grgurovic.pdf

Henderson, M., Selwyn, N., \& Aston, R. (2017). What works and why? Student perceptions of 'useful' digital technology in university teaching and learning. Studies in Higher Education, 42(8), 1567 1579. https://doi.org/10.1080/03075079.2015.1007946

Henrie, C. R., Halverson, L. R., \& Graham, C. R. (2015). Measuring student engagement in technologymediated learning: A review. Computers \& Education, 90, 36-53. https://doi.org/10.1016/j.compedu.2015.09.005

Hew, K. F., Lan, M., Tang, Y., Jia, C., \& Lo, C. K. (2019). Where is the "theory" within the field of educational technology research? British Journal of Educational Technology, 50(3), 956-971. https://doi.org/10.1111/bjet.12770

Huang, C-T., \& Yang, S. C. (2015). Effects of online reciprocal teaching on reading strategies, comprehension, self-efficacy, and motivation. Journal of Educational Computing Research, 52(3), 381-407. https://doi.org/10.1177/0735633115571924

Hung, H-T. (2015). Intentional vocabulary learning using digital flashcards. English Language Teaching, 8(10), 107-112. http://dx.doi.org/10.5539/elt.v8n10p107

Hung, H-T., Yang, J. C., Hwang, G-J., Chu, H-C., \& Wang, C-C. (2018). A scoping review of research on digital game-based language learning. Computers \& Education, 126, 89-104. https://doi.org/10.1016/j.compedu.2018.07.001

Kahu, E. R. (2013). Framing student engagement in higher education. Studies in Higher Education, 38(5), 758-773. https://doi.org/10.1080/03075079.2011.598505

Kelley, K., Lai, K., Lai, M. K., \& Suggests, M. (2018). Package “MBESS.” Retrieved from https://cran.rproject.org/web/packages/MBESS/MBESS.pdf

Kenny, M. A. (2008). Discussion, cooperation, collaboration: The impact of task structure on student interaction in a web-based translation exercise module. Interpreter and Translator Trainer, 2(2), 139 164. https://doi.org/10.1080/1750399X.2008.10798771

Krasnova, T., \& Vanushin, I. (2016). Blended learning perception among undergraduate engineering students. International Journal of Emerging Technologies in Learning (iJET), 11(01), 54-56. https://doi.org/10.3991/ijet.v11i01.4901

Kupper, L. L., \& Hafner, K. B. (1989). How appropriate are popular sample size formulas? The American Statistician, 43(2), 101-105. Retrieved from https://www.jstor.org/stable/2684511

Lai, J. W.M., \& Bower, M. (2019). How is the use of technology in education evaluated? A systematic review. Computers \& Education, 133, 27-42. https://doi.org/10.1016/j.compedu.2019.01.010

Lin, W-C., \& Yang, S. C. (2013). Exploring the roles of Google.doc and peer e-tutors in English writing. English Teaching: Practice and Critique, 12(1), 79-90. Retrieved from http://files.eric.ed.gov/fulltext/EJ1017168.pdf

Lopera Medina, S. (2014). Motivation conditions in a foreign language reading comprehension course offering both a web-based modality and a face-to-face modality. PROFILE, 16(1), 89-104. https://doi.org/10.15446/profile.v16n1.36939

Lu, J., \& Churchill, D. (2014). The effect of social interaction on learning engagement in a social networking environment. Interactive Learning Environments, 22(4), 401-417. https://doi.org/10.1080/10494820.2012.680966

Lu, Z., Hou, L., \& Huang, X. (2010). A research on a student-centred teaching model in an ICT-based English audio-video speaking class. International Journal of Education and Development Using Information and Communication Technology, 6(3), 101-123. Retrieved from https://files.eric.ed.gov/fulltext/EJ1085029.pdf

Mahatmya, D., Lohman, B. J., Matjasko, J. L., \& Farb, A. F. (2012). Engagement across developmental periods. In S. L. Christenson, A. L. Reschly, \& C. Wylie (Eds.), Handbook of Research on Student 
Engagement (pp. 45-63). Boston, MA: Springer US. Retrieved from http://link.springer.com/10.1007/978-1-4614-2018-7 3

Martin, A. J. (2012). Part II Commentary: Motivation and engagement: Conceptual, operational, and empirical clarity. In S. L. Christenson, A. L. Reschly, \& C. Wylie (Eds.), Handbook of Research on Student Engagement (Vol. 52, pp. 303-311). Boston, MA: Springer US. https://doi.org/10.1007/9781-4614-2018-7 14

Mejia, G. (2016). Promoting language learning: The use of mLearning in Spanish classes. Revista de Lenguas Para Fines Específicos, 22(1), 80-99. Retrieved from https://dialnet.unirioja.es/descarga/articulo/6677873.pdf

Moher, D., Liberati, A., Tetzlaff, J., \& Altman, D. (2009). Preferred reporting items for systematic reviews and meta-analyses: The PRISMA statement. British Medical Journal, 339(b2535), 1-8. https://doi.org/10.1136/bmj.b2535

Morris, S. B. (2008). Estimating effect sizes from pretest-post-test-control group designs. Organizational Research Methods, 11(2), 364-386. https://doi.org/10.1177/1094428106291059

Nielsen, B. (2013). Students' perceptions and learning outcomes of online writing using discussion boards. JALT CALL Journal, 9(2), 131-147. Retrieved from http://files.eric.ed.gov/fulltext/EJ1107983.pdf

Oliver, B., \& Jorre de St Jorre, T. (2018). Graduate attributes for 2020 and beyond: Recommendations for Australian higher education providers. Higher Education Research \& Development, 37(4), 821-836. https://doi.org/10.1080/07294360.2018.1446415

Orawiwatnakul, W., \& Wichadee, S. (2016). Achieving better learning performance through the discussion activity in facebook. Turkish Online Journal of Educational Technology, 15(3), 1-8. Retrieved from http://files.eric.ed.gov/fulltext/EJ1106404.pdf

Organization for Economic Cooperation and Development (2015). Schooling redesigned. https://doi.org/10.1787/9789264245914-en

Pattanapichet, F., \& Wichadee, S. (2015). Using space in social media to promote undergraduate students' critical thinking skills. Turkish Online Journal of Distance Education, 16(4), 38-49. https://doi.org/10.17718/tojde.94170

Payne, L. (2017). Student engagement: Three models for its investigation. Journal of Further and Higher Education, 3(2), 1-17. https://doi.org/10.1080/0309877X.2017.1391186

Peck, J. J. (2012). Keeping it social: Engaging students online and in class. Asian Social Science, 8(14). https://doi.org/10.5539/ass.v8n14p81

Pekrun, R., \& Linnenbrink-Garcia, L. (2012). Academic emotions and student engagement. In S. L. Christenson, A. L. Reschly, \& C. Wylie (Eds.), Handbook of Research on Student Engagement (pp. 259-282). Boston, MA: Springer. https://doi.org/10.1007/978-1-4614-2018-7 12

Pérez-Sanagustín, M., Nussbaum, M., Hilliger, I., Alario-Hoyos, C., Heller, R. S., Twining, P., \& Tsai, CC. (2017). Research on ICT in K-12 schools - A review of experimental and survey-based studies in Computers \& Education 2011 to 2015. Computers \& Education, 104, A1-A15. https://doi.org/10.1016/j.compedu.2016.09.006

Peterson, M. (2009). Learner interaction in synchronous CMC: A sociocultural perspective. Computer Assisted Language Learning, 22(4), 303-321. https://doi.org/10.1080/09588220903184690

Peterson, M. (2012). EFL learner collaborative interaction in Second Life. ReCALL, 24(01), $20-39$. https://doi.org/10.1017/S0958344011000279

Ramamuruthy, V., \& Rao, S. (2015). Smartphones promote autonomous learning in ESL classrooms. Malaysian Online Journal of Educational Technology, 3(4), 23-35. Retrieved from http://files.eric.ed.gov/fulltext/EJ1085930.pdf

Redecker, C., \& Punie, Y. (2017). European framework for the digital competence of educators. Luxembourg: Publications Office of the European Union. Retrieved from http://publications.jrc.ec.europa.eu/repository/bitstream/JRC107466/pdf_digcomedu_a4_final.pdf

Redmond, P., Heffernan, A., Abawi, L., Brown, A., \& Henderson, R. (2018). An online engagement framework for higher education. Online Learning, 22(1). https://doi.org/10.24059/olj.v22i1.1175

Reeve, J. (2012). A self-determination theory perspective on student engagement. In S. L. Christenson, A. L. Reschly, \& C. Wylie (Eds.), Handbook of Research on Student Engagement (pp. 149-172). Boston, MA: Springer US. Retrieved from http://link.springer.com/10.1007/978-1-4614-2018-7_ 7

Sauro, S. (2009). Computer-mediated corrective feedback and the development of L2 grammar. Language Learning \& Technology, 13(1), 96-120. Retrieved from https://scholarspace.manoa.hawaii.edu/bitstream/10125/44170/1/13_01_sauro.pdf 
Schindler, L. A., Burkholder, G. J., Morad, O. A., \& Marsh, C. (2017). Computer-based technology and student engagement: A critical review of the literature. International Journal of Educational Technology in Higher Education, 14(1). https://doi.org/10.1186/s41239-017-0063-0

Selwyn, N. (2016). Digital downsides: exploring university students' negative engagements with digital technology. Teaching in Higher Education, 21(8), 1006-1021. https://doi.org/10.1080/13562517.2016.1213229

Shi, Z. J., \& Luo, G. F. (2016). Application of WeChat teaching platform in interactive translation teaching. International Journal of Emerging Technologies in Learning, 11(9), 71-75. https://doi.org/10.3991/ijet.v11i09.6113

Skinner, E., \& Pitzer, J. R. (2012). Developmental dynamics of student engagement, coping, and everyday resilience. In S. L. Christenson, A. L. Reschly, \& C. Wylie (Eds.), Handbook of Research on Student Engagement (pp. 21-44). Boston, MA: Springer US. https://doi.org/10.1007/978-1-46142018-7 2

Smith, K., \& Craig, H. (2013). Enhancing the autonomous use of CALL: A new curriculum model in EFL. CALICO Journal, 30(2), 252-278. Retrieved from https://journals.equinoxpub.com/index.php/CALICO/article/viewFile/22957/18963

Smith, K. A., Sheppard, S. D., Johnson, D. W., \& Johnson, R. T. (2005). Pedagogies of engagement: Classroom-based practices. Journal of Engineering Education, 94(1), 87-101. https://doi.org/10.1002/j.2168-9830.2005.tb00831.x

Song, M., \& Liu, J. N. (2013). The interpersonal interaction in computer supported collaborative learning environment. International Journal on E-Learning, 12(3), 329-351. Retrieved from https://www.learntechlib.org/primary/p/36159/

Sun, L. (2014). Investigating the effectiveness of Moodle-based blended learning in college English courses. International Journal of Information Technology and Management, 13(1), 83-94. https://doi.org/10.1504/IJITM.2014.059152

Sun, Y-C. (2012). Examining the effectiveness of extensive speaking practice via voice blogs in a foreign language learning context. CALICO Journal, 29(3), 494-506. Retrieved from https://journals.equinoxpub.com/CALICO/article/viewFile/23722/19727

Tamim, R. M., Bernard, R. M., Borokhovski, E., Abrami, P. C., \& Schmid, R. F. (2011). What forty years of research says about the impact of technology on learning: A second-order meta-analysis and validation study. Review of Educational Research, 81(1), 4-28. https://doi.org/10.3102/0034654310393361

Thorne, S. L., Black, R. W., \& Sykes, J. M. (2009). Second language use, socialization, and learning in internet interest communities and online gaming. The Modern Language Journal, 93(s1), 802-821. https://doi.org/10.1111/j.1540-4781.2009.00974.x

Tsai S-C. (2012). Integration of multimedia courseware into ESP instruction for technological purposes in higher technical education. Journal of Educational Technology \& Society, 15(2), 50-61. Retrieved from https://www.semanticscholar.org/paper/Integration-of-Multimedia-Courseware-into-ESP-forTsai/95adcf4b68ea4bf60ad23841317a3ae98c12c35d

Tschirhart, C., \& Rigler, E. (2009). LondonMet e-Packs: A pragmatic approach to learner/teacher autonomy. Language Learning Journal, 37(1), 71-83. https://doi.org/10.1080/09571730802404394

United Nations Educational, Scientific and Cultural Organization Institute for Statistics (2015). International standard classification of education: Fields of education and training 2013. https://doi.org/10.15220/978-92-9189-179-5-en

Wang, M. (2010). Online collaboration and offline interaction between students using asynchronous tools in blended learning. Australasian Journal of Educational Technology, 26(6), 830-846. https://doi.org/10.14742/ajet.1045

$\mathrm{Wu}, \mathrm{S}$. Y. (2016). The effect of teaching strategies and students' cognitive style on the online discussion environment. Asia-Pacific Education Researcher, 25(2), 267-277. https://doi.org/10.1007/s40299$\underline{015-0259-9}$

$\mathrm{Xu}$, H. L., \& Moloney, R. (2011). "It makes the whole learning experience better": Student feedback on the use of the interactive whiteboard in learning Chinese at tertiary level. Asian Social Science, 7(11), 20-29. https://doi.org/10.5539/ass.v7n11p20

Yang, Y-F., \& Hsieh, P-Y. (2015). Negotiation of meaning to comprehend hypertexts through peer questioning. Language Learning \& Technology, 19(2), 69-84. Retrieved from https://scholarspace.manoa.hawaii.edu/bitstream/10125/44418/1/19_02_yanghsieh.pdf 
Yang, Y-T. C., Gamble, J., \& Tang, S-Y. S. (2012). Voice over instant messaging as a tool for enhancing the oral proficiency and motivation of English-as-a-foreign-language learners. British Journal of Educational Technology, 43(3), 448-464. https://doi.org/10.1111/j.1467-8535.2011.01204.x

Yildiz, S. (2009). Social presence in the web-based classroom: Implications for intercultural communication. Journal of Studies in International Education, 13(1), 46-65. https://doi.org/10.1177/1028315308317654

Zepke, N. (2014). Student engagement research in higher education: questioning an academic orthodoxy. Teaching in Higher Education, 19(6), 697-708. https://doi.org/10.1080/13562517.2014.901956

Zepke, N. (2018). Student engagement in neo-liberal times: What is missing? Higher Education Research \& Development, 37(2), 433-446. https://doi.org/10.1080/07294360.2017.1370440

Zhang, H., Song, W., Shen, S., \& Huang, R. (2014). The effects of blog-mediated peer feedback on learners' motivation, collaboration, and course satisfaction in a second language writing course. Australasian Journal of Educational Technology, 30(6), 670-685. https://doi.org/10.14742/ajet.860

Zhang, W., \& Han, C. (2012). A case study of the application of a blended learning approach to webbased college English teaching platform in a medical university in eastern China. Theory and Practice in Language Studies, 2(9), 1961-1970. https://doi.org/10.4304/tpls.2.9.1961-1970

Corresponding author: Melissa Bond, melissa.bond@uni-oldenburg.de

Copyright: Articles published in the Australasian Journal of Educational Technology (AJET) are available under Creative Commons Attribution Non-Commercial No Derivatives Licence (CC BYNC-ND 4.0). Authors retain copyright in their work and grant AJET right of first publication under CC BY-NC-ND 4.0.

Please cite as: Bedenlier, S., Bond, M., Buntins, K., Zawacki-Richter, O., \& Kerres, M. (2020). Facilitating student engagement through educational technology in higher education: A systematic review in the field of arts and humanities. Australasian Journal of Educational Technology, 36(4), 126-150. https://doi.org/10.14742/ajet.5477 


\section{Appendix A \\ Facets of engagement and disengagement}

\section{Facets of student engagement}

\begin{tabular}{|l|l|l|}
\hline \multicolumn{1}{|c|}{ Cognitive engagement } & \multicolumn{1}{c|}{ Affective engagement } & Behavioural engagement \\
\hline Purposeful & Enthusiasm & Attendance \\
\hline Integrating ideas & Sense of belonging & Study habits \\
\hline Doing extra to learn more & Satisfaction & Developing agency \\
\hline Follow through/care/thoroughness & Curiosity & Participation/involvement \\
\hline Positive self-perceptions \& self-efficacy & Sees relevance & Developing multidisciplinary skills \\
\hline Preference for challenging tasks & $\begin{array}{l}\text { Sense of connectedness to } \\
\text { school/university }\end{array}$ & Attention/focus \\
\hline Teaching self \& peers & $\begin{array}{l}\text { Positive interactions with peers \& } \\
\text { teachers }\end{array}$ & Time on task/staying on task/persistence \\
\hline Use of sophisticated learning strategies & $\begin{array}{l}\text { Positive attitude about learning/values } \\
\text { learning }\end{array}$ & $\begin{array}{l}\text { Interaction (peers, teacher, content, } \\
\text { technology) }\end{array}$ \\
\hline Positive perceptions of teacher support & Interest & Accessing course material \\
\hline Critical thinking & Enjoyment & Identifying opportunities and challenges \\
\hline Setting learning goals & Sense of wellbeing & Supporting \& encouraging peers \\
\hline Self-regulation & Pride & Attempting \\
\hline Operational reasoning & Vitality/zest & Homework completion \\
\hline Trying to understand & Excitement & Positive conduct \\
\hline Reflection & Desire to do well & Action/initiation \\
\hline Concentration/focus & Feeling appreciated & Confidence \\
\hline Deep learning & Manages expectations & Assuming responsibility \\
\hline Learning from peers & & Asking teacher or peers for help \\
\hline Justifying decisions & & \\
\hline
\end{tabular}

\section{Facets of student disengagement}

\begin{tabular}{|l|l|l|}
\hline \multicolumn{1}{|c|}{ Cognitive disengagement } & \multicolumn{1}{c|}{ Affective disengagement } & \multicolumn{1}{c|}{ Behavioural disengagement } \\
\hline Aimless & Boredom & Procrastination \\
\hline Unwilling & Anger & Half-hearted \\
\hline Apathy & Shame & Mentally withdrawn \\
\hline Helpless & Dislike & Absent \\
\hline Opposition/rejection & Disinterest & Giving up \\
\hline Hopeless & Sadness & Unfocused/inattentive \\
\hline Resigned & Self-blame & Burned out/exhausted \\
\hline Avoidance & Disappointment & Poor conduct \\
\hline Pressured & Frustration & Restlessness \\
\hline & Worry/anxiety & Distracted \\
\hline & Overwhelmed & Unprepared \\
\hline & & Task incompletion \\
\hline
\end{tabular}

Sourced from a range of literature:

Appleton, Christenson, \& Furlong, 2008; Filsecker \& Kerres, 2014; Fredricks et al., 2016; Fredricks, Blumenfeld, \& Paris, 2004; Henrie, Halverson, \& Graham, 2015; Kahu, 2013; Mahatmya, Lohman, Matjasko, \& Farb, 2012; Martin, 2012; Redmond, Heffernan, Abawi, Brown, \& Henderson, 2018; Reeve, 2012; Skinner \& Pitzer, 2012; Zepke, 2014

See also Bond \& Bedenlier, 2019, p. 3 
Appendix B

Educational technology tool typology, based on Bower (2016)

\begin{tabular}{|c|c|c|c|c|}
\hline Text-based tools & $\begin{array}{c}\text { Multimodal } \\
\text { production tools }\end{array}$ & $\begin{array}{l}\text { Website creation } \\
\text { tools }\end{array}$ & $\begin{array}{c}\text { Knowledge } \\
\text { organisation and } \\
\text { sharing }\end{array}$ & $\begin{array}{l}\text { Data analysis } \\
\text { tools }\end{array}$ \\
\hline $\begin{array}{l}\text { Discussion } \\
\text { forums } \\
\text { Collaborative } \\
\text { writing tools } \\
\text { Readings } \\
\text { Newsletter } \\
\text { Text } \\
\text { RSS } \\
\text { Interactive } \\
\text { textbook } \\
\text { Annotation tools } \\
\text { Email } \\
\text { Chat } \\
\text { Instant messaging } \\
\text { Wikis }\end{array}$ & $\begin{array}{l}\text { Animations } \\
\text { Tutorials } \\
\text { Recorded lectures } \\
\text { Videos } \\
\text { Podcast/Vodcast } \\
\text { Screencast } \\
\text { Authoring tools } \\
\text { Voice recorder }\end{array}$ & $\begin{array}{l}\text { Blogs } \\
\text { ePortfolios }\end{array}$ & $\begin{array}{l}\text { Cloud storage } \\
\text { Bookmarking } \\
\text { LMS } \\
\text { Diary tool in } \\
\text { Moodle }\end{array}$ & $\begin{array}{l}\text { Learning } \\
\text { analytics } \\
\text { dashboard }\end{array}$ \\
\hline $\begin{array}{c}\text { Digital } \\
\text { Storytelling tools }\end{array}$ & Assessment tools & $\begin{array}{l}\text { Social networking } \\
\text { tools }\end{array}$ & $\begin{array}{c}\text { Synchronous } \\
\text { collaboration } \\
\text { tools }\end{array}$ & Mobile learning \\
\hline Storyboards & $\begin{array}{l}\text { eAssessment } \\
\text { Quizzes } \\
\text { ARS } \\
\text { Open badges }\end{array}$ & $\begin{array}{l}\text { Social platforms } \\
\text { Microblogging }\end{array}$ & $\begin{array}{l}\text { Audio-Video } \\
\text { conferencing }\end{array}$ & $\begin{array}{l}\text { Apps } \\
\text { mLearning }\end{array}$ \\
\hline Virtual worlds & Learning software & Online learning & Hardware & Peer e-tutors \\
\hline $\begin{array}{l}\text { Virtual lab } \\
\text { Simulations } \\
\text { Virtual worlds }\end{array}$ & $\begin{array}{l}\text { Language learning } \\
\text { software } \\
\text { Presentation } \\
\text { software }\end{array}$ & Homepage & $\begin{array}{l}\text { Tablets } \\
\text { Hardware } \\
\text { Interactive } \\
\text { whiteboards }\end{array}$ & Peer e-tutors \\
\hline
\end{tabular}

\section{Games}

Games 


\section{Appendix C Arts and humanities study characteristics in this sample}

\begin{tabular}{|c|c|c|c|c|}
\hline Author & Year & Journal & Citations & Field of Study \\
\hline Alshaikhi \& Madini & 2016 & English Language Teaching & 2 & English \\
\hline Asoodar et al. & 2014 & Computers in Human Behavior & 7 & English \\
\hline $\begin{array}{l}\text { Carver et al. (Study } \\
\text { 1) }\end{array}$ & 2012 & Learning and Media & 7 & $\begin{array}{l}\text { Introduction to the } \\
\text { Study of the Arab } \\
\text { World }\end{array}$ \\
\hline $\begin{array}{l}\text { Carver et al. (Study } \\
\text { 2) }\end{array}$ & 2012 & Learning and Media & 7 & $\begin{array}{l}\text { Woman Health \& } \\
\text { Human Rights }\end{array}$ \\
\hline Chen \& Chang & 2014 & $\begin{array}{l}\text { Interactive Learning } \\
\text { Environments }\end{array}$ & 28 & Chinese \\
\hline Cheung & 2015 & $\begin{array}{l}\text { Communications in Computer and } \\
\text { Information Science }\end{array}$ & 11 & Various languages \\
\hline Ducate et al. & 2011 & Foreign Language Annals & 77 & Various languages \\
\hline Fukuzawa \& Boyd & 2016 & $\begin{array}{l}\text { The Canadian Journal for the } \\
\text { Scholarship of Teaching and } \\
\text { Learning }\end{array}$ & 5 & Anthropology \\
\hline $\begin{array}{l}\text { García-Sánchez \& } \\
\text { Sol Rojas-Lizana }\end{array}$ & 2012 & $\begin{array}{l}\text { Technology, Pedagogy and } \\
\text { Education }\end{array}$ & 23 & English \\
\hline $\begin{array}{l}\text { Grgurović \& } \\
\text { Hegelheimer }\end{array}$ & 2007 & $\begin{array}{l}\text { Language Learning and } \\
\text { Technology }\end{array}$ & 175 & English \\
\hline Huang \& Yang & 2015 & $\begin{array}{l}\text { Journal of Educational Computing } \\
\text { Research }\end{array}$ & 18 & English \\
\hline Hung & 2015 & English Language Teaching & 13 & English \\
\hline Kenny & 2008 & Interpreter and Translator Trainer & 19 & Translation studies \\
\hline $\begin{array}{l}\text { Krasnova \& } \\
\text { Vanushin }\end{array}$ & 2016 & $\begin{array}{l}\text { International Journal of Emerging } \\
\text { Technologies in Learning }\end{array}$ & 9 & English \\
\hline Lin \& Yang & 2013 & $\begin{array}{l}\text { English Teaching: Practice and } \\
\text { Critique }\end{array}$ & 20 & English \\
\hline Lopera Medina & 2014 & $\begin{array}{l}\text { PROFILE: Issues in Teachers' } \\
\text { Professional Development }\end{array}$ & 13 & English \\
\hline Lu \& Churchill & 2014 & $\begin{array}{l}\text { Interactive Learning } \\
\text { Environments }\end{array}$ & 50 & Literature \\
\hline Lu et al. & 2010 & $\begin{array}{l}\text { International Journal of Education } \\
\text { and Development using } \\
\text { Information and Communication } \\
\text { Technology }\end{array}$ & 47 & English \\
\hline Mejia & 2016 & $\begin{array}{l}\text { Lfe-Revista De Lenguas Para } \\
\text { Fines Especificos }\end{array}$ & 1 & Spanish \\
\hline Nielsen & 2013 & JALT CALL Journal & 11 & English \\
\hline $\begin{array}{l}\text { Orawiwatnakul \& } \\
\text { Wichadee }\end{array}$ & 2016 & $\begin{array}{l}\text { Turkish Online Journal of } \\
\text { Educational Technology }\end{array}$ & 5 & English \\
\hline $\begin{array}{l}\text { Pattanapichet \& } \\
\text { Wichadee }\end{array}$ & 2015 & $\begin{array}{l}\text { Turkish Online Journal of } \\
\text { Distance Education }\end{array}$ & 7 & English \\
\hline Peck & 2012 & Asian Social Science & 21 & Linguistics \\
\hline Peterson & 2012 & Recall & 76 & English \\
\hline Peterson & 2009 & $\begin{array}{l}\text { Computer Assisted Language } \\
\text { Learning }\end{array}$ & 83 & English \\
\hline $\begin{array}{l}\text { Ramamuruthy \& } \\
\text { Rao }\end{array}$ & 2015 & $\begin{array}{l}\text { Malaysian Online Journal of } \\
\text { Educational Technology }\end{array}$ & 11 & English \\
\hline Sauro & 2009 & $\begin{array}{l}\text { Language Learning \& } \\
\text { Technology }\end{array}$ & 225 & English \\
\hline
\end{tabular}




\begin{tabular}{|c|c|c|c|c|}
\hline Shi \& Luo & 2016 & $\begin{array}{l}\text { International Journal of Emerging } \\
\text { Technologies in Learning }\end{array}$ & 6 & English \\
\hline Smith \& Craig & 2013 & CALICO Journal & 20 & English \\
\hline Song \& Liu & 2013 & $\begin{array}{l}\text { International Journal on E- } \\
\text { Learning }\end{array}$ & 0 & Literature \\
\hline Sun & 2012 & CALICO Journal & 11 & English \\
\hline Sun & 2014 & $\begin{array}{l}\text { International Journal of } \\
\text { Information Technology and } \\
\text { Management }\end{array}$ & 33 & English \\
\hline Tsai & 2012 & $\begin{array}{l}\text { Journal of Educational } \\
\text { Technology \& Society }\end{array}$ & 22 & English \\
\hline Tschirhart \& Rigler & 2009 & Language Learning Journal & 10 & Foreign language \\
\hline Wang & 2010 & $\begin{array}{l}\text { Australasian Journal of } \\
\text { Educational Technology }\end{array}$ & 77 & English \\
\hline $\mathrm{Wu}$ & 2016 & $\begin{array}{l}\text { Asia-Pacific Education } \\
\text { Researcher }\end{array}$ & 1 & Chinese \\
\hline $\mathrm{Xu} \&$ Moloney & 2011 & Asian Social Science & 25 & Chinese \\
\hline Yang et al. & 2012 & $\begin{array}{l}\text { British Journal of Educational } \\
\text { Technology }\end{array}$ & 34 & English \\
\hline Yang \& Hsieh & 2015 & $\begin{array}{l}\text { Language Learning \& } \\
\text { Technology }\end{array}$ & 2 & English \\
\hline Yildiz & 2009 & $\begin{array}{l}\text { Journal of Studies in International } \\
\text { Education }\end{array}$ & 54 & English \\
\hline Zhang \& Han & 2012 & $\begin{array}{l}\text { Theory and Practice in Language } \\
\text { Studies }\end{array}$ & 16 & English \\
\hline Zhang et al. & 2014 & $\begin{array}{l}\text { Australasian Journal of } \\
\text { Educational Technology }\end{array}$ & 18 & English \\
\hline
\end{tabular}

